\title{
A Conceptual Life-History Model for Pallid and Shovelnose Sturgeon
}

circular 1315 


\section{Cover Photographs}

1 Shovelnose and pallid sturgeon (photograph by A.J. DeLonay, U.S. Geological Survey).

2 Pallid sturgeon (photograph by A.J. DeLonay, U.S. Geological Survey).

3 Missouri River taken from the overlook at Ponca State Park, Ponca, Nebraska (photograph by E.C. Troutt, U.S. Geological Survey).
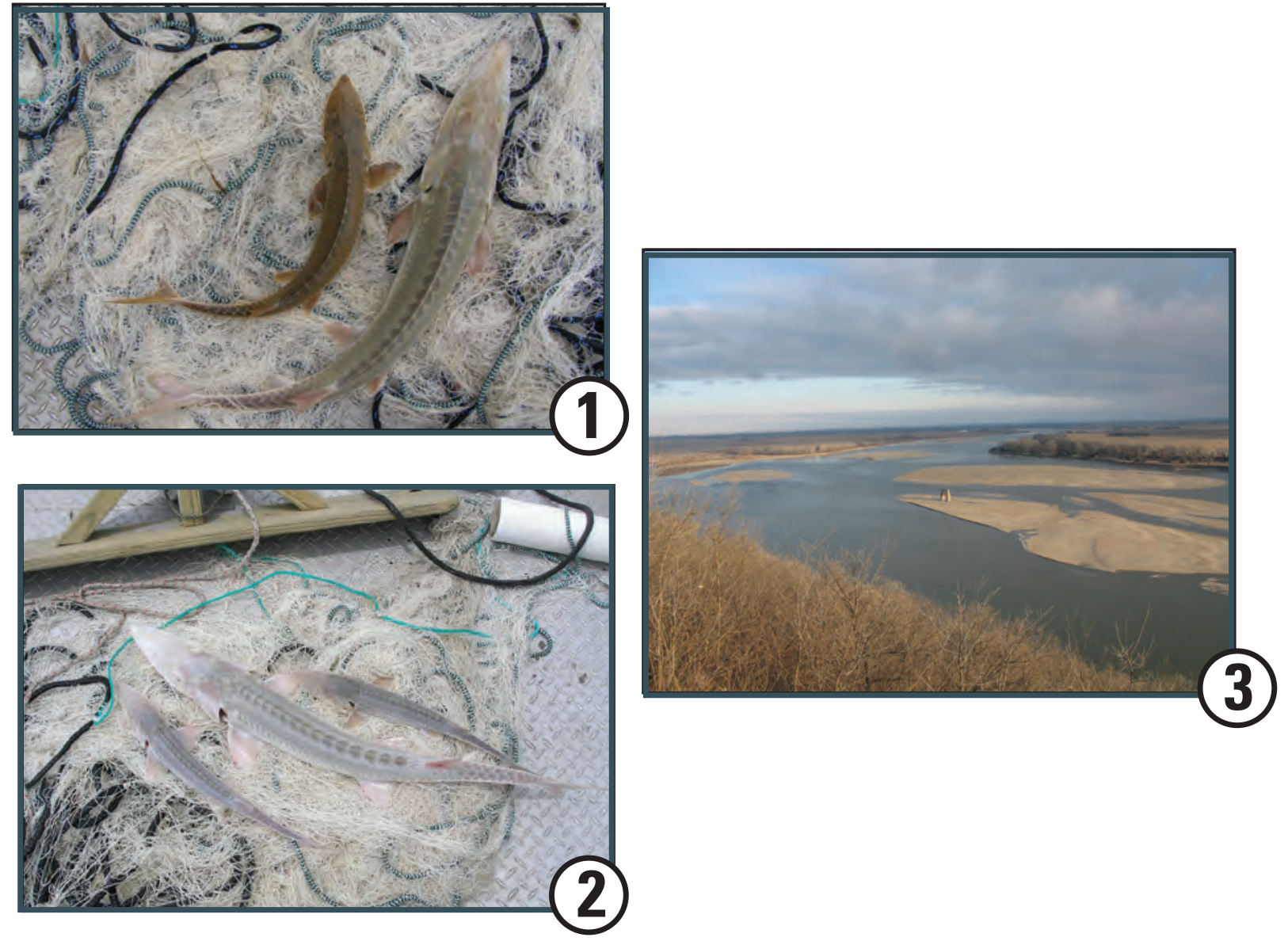


\section{A Conceptual Life-History Model for Pallid and Shovelnose Sturgeon}

By Mark L. Wildhaber, Aaron J. DeLonay, Diana M. Papoulias, David L. Galat, Robert B. Jacobson, Darin G. Simpkins, Patrick J. Braaten, Carl E. Korschgen, and Michael J. Mac

Circular 1315 


\title{
U.S. Department of the Interior DIRK KEMPTHORNE, Secretary
}

\section{U.S. Geological Survey \\ Mark D. Myers, Director}

\author{
U.S. Geological Survey, Reston, Virginia: 2007 \\ Reprinted: 2008
}

\author{
For product and ordering information: \\ World Wide Web: http://www.usgs.gov/pubprod \\ Telephone: 1-888-ASK-USGS \\ For more information on the USGS--the Federal source for science about the Earth, its natural and living resources, \\ natural hazards, and the environment: \\ World Wide Web: http://www.usgs.gov \\ Telephone: 1-888-ASK-USGS
}

\begin{abstract}
Any use of trade, product, or firm names is for descriptive purposes only and does not imply endorsement by the U.S. Government.

Although this report is in the public domain, permission must be secured from the individual copyright owners to reproduce any copyrighted materials contained within this report.
\end{abstract}

Suggested citation:

Wildhaber, M.L., DeLonay, A.J., Papoulias, D.M., Galat, D.L., Jacobson, R.B., Simpkins, D.G., Braaten, P.J., Korschgen, C.E., and Mac, M.J., 2007, A conceptual life-history model for pallid and shovelnose sturgeon: U.S. Geological Survey Circular 1315, $18 \mathrm{p}$ 


\section{Contents}

Abstract
Introduction.
Purpose and Scope
Basis for the Conceptual Life-History Model
Structure of the Conceptual Life-History Model
Processes and Conditions Controlling Life-Stage Transitions
Spature to Pre-Spawning to Spawning Adult
Developing Embryo to Free Embryo Embryo to Larval Stage of Exogenous Feeding
Jurval Stage of Exogenous Feeding to Juveniles to Immature Adult
Population-Forecasting Model.

\section{Figures}

1. Factors that may affect reproduction and survival of sturgeons .......................................

2-9. Charts showing-

2. Conceptual model of Scaphirhynchus sturgeon life history ....................................

3. Symbols and labels used in submodels of Scaphirhynchus sturgeon conceptual model .............................................................................................

4. Submodel for the transition from mature to pre-spawning adult in the Scaphirhynchus sturgeon life-history conceptual model........................................7

5. Submodel for the transition from spawning adults with viable gametes to developing embryos in the Scaphirhynchus sturgeon life-history conceptual

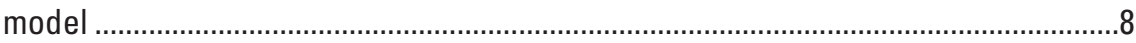

6. Submodel for the transition from developing embryo to free embryo in the Scaphirhynchus sturgeon life-history conceptual model......................................... 9

7. Submodel for the transition from free embryo to larval stage of exogenous feeding in the Scaphirhynchus sturgeon life-history conceptual model.................10

8. Submodel for the transition from larval stage of exogenous feeding to juveniles in the Scaphirhynchus sturgeon life-history conceptual model..

9. Submodel for the transition from juvenile to immature adult in the Scaphirhynchus sturgeon life-history conceptual model. 


\section{Conversion Factors}

\begin{tabular}{|c|c|c|}
\hline Multiply & By & To obtain \\
\hline \multirow{2}{*}{\multicolumn{3}{|c|}{ Length }} \\
\hline & 0.03937 & inch (in.) \\
\hline
\end{tabular}

Temperature in degrees Celsius $\left({ }^{\circ} \mathrm{C}\right)$ may be converted to degrees Fahrenheit $\left({ }^{\circ} \mathrm{F}\right)$ as follows:

${ }^{\circ} \mathrm{F}=\left(1.8 x^{\circ} \mathrm{C}\right)+32$ 


\title{
A Conceptual Life-History Model for Pallid and Shovelnose Sturgeon
}

\author{
By Mark L. Wildhaber, Aaron J. DeLonay, Diana M. Papoulias, David L. Galat, Robert B. Jacobson, \\ Darin G. Simpkins, Patrick J. Braaten, Carl E. Korschgen, and Michael J. Mac
}

\section{Abstract}

Intensive management of the Missouri and Mississippi Rivers has resulted in dramatic physical changes to these rivers. These changes have been implicated as causative agents in the decline of pallid sturgeon. The pallid sturgeon, federally listed as endangered, is endemic to the turbid waters of the Missouri River and the Lower Mississippi River. The sympatric shovelnose sturgeon historically was more common and widespread than the pallid sturgeon. Habitat alteration, river regulation, pollution, and over-harvest have resulted in the now predictable patterns of decline and localized extirpation of sturgeon across species and geographic areas. Symptomatic of this generalized pattern of decline is poor reproductive success, and low or no recruitment of wild juveniles to the adult population. The purpose of this report is to introduce a conceptual life-history model of the factors that affect reproduction, growth, and survival of shovelnose and pallid sturgeons. The conceptual model provided here was developed to organize the understanding about the complex life history of Scaphirhynchus sturgeons. It was designed to be used for communication, planning, and to provide the structure for a population-forecasting model. These models are intended to be dynamic and responsive to new information and changes in river management, thereby providing scientists, stakeholders, and managers with ways to improve understanding of the effects of management actions on the ecological requirements of Scaphirhynchus sturgeons. As new scientific knowledge becomes available, it could be included in the model in many ways at various integration levels.

\section{Introduction}

Intensive management of the Missouri and Mississippi Rivers for purposes of navigation, flood control, and power generation has resulted in dramatic physical changes to these rivers (Ferrell, 1993; Ferrell, 1996; Galat and Lipkin, 2000). Historically, these rivers were characterized by a shifting, braided channel with abundant sandbars and accumulations of large woody debris. The shifting channel contained a wide variety of hydraulic environments that provided diverse habitat for many benthic fish species. In the 1800's, training into a fast, deep, and single-thread channel to support navigation was begun. Wing dikes concentrated flow, and revetments and levees kept the channels in place and disconnected it from the flood plains. Reservoir regulation substantially changed the annual hydrograph, sediment load, and temperature regime of the Missouri and Mississippi Rivers. As in other large flood-plain rivers, agricultural pesticides, nutrient runoff, and increasing discharge of domestic and industrial effluents affect the aquatic biota and the ecological health of the Missouri River Basin (Tockner and Stanford, 2000). Proliferation of introduced and non-indigenous species has further threatened to diminish the ecological integrity of the river ecosystem (Pflieger, 1997; Galat and others, 2005). Together these changes in flow, channel morphology, water quality, and biota have been implicated as causative agents in the dramatic declines in native river fishes and their resource base in general, and with the decline of pallid sturgeon (Scaphirhynchus albus) in particular (Funk and Robinson, 1974; Hesse and others, 1989; Hesse and Sheets, 1993; Galat and others, 2005).

Since 1989, Missouri River Basin management agencies have been involved in revising the U.S. Army Corps of Engineers' operating plan for the Missouri River mainstem reservoirs, and consulting on the implementation of the navigation and bank stabilization projects (U.S. Fish and Wildlife Service, 2000, 2003). As a result, several significant management activities have been initiated to benefit the endangered pallid sturgeon in the Lower Missouri River, including propagation efforts to supplement wild populations, physical habitat rehabilitation projects to improve riverine habitat conditions, and planned experimental reservoir releases to promote reproduction and increased survival of juvenile pallid sturgeon.

The pallid sturgeon is endemic to the turbid waters of the Missouri River and the Lower Mississippi River, from the mouth of the Missouri River downstream to New Orleans (Mayden and Kuhajda, 1997). The pallid sturgeon is rare throughout the Missouri River Basin and was federally listed as an endangered species in 1990 (Dryer and Sandvol, 1993). In the Lower Missouri River, no reliable pallid sturgeon population estimates exist; however, based on recent capture rates and the incidence of occurrence, managers estimate that 
only several thousand individuals remain in the Lower Missouri River (Duffy and others, 1996; U.S. Fish and Wildlife Service, 2000). Less than 200 wild pallid sturgeon are estimated to exist in the Upper Missouri River (Kapuscinski, 2002). Hybridization of pallid sturgeon with the sympatric and closely related shovelnose sturgeon ( $S$. platorynchus) has been documented and identified as a potentially serious threat to the persistence of the species (Carlson and others, 1985; Keenlyne and others, 1994; Wills and others, 2002).

The shovelnose sturgeon historically was more common and widespread than the pallid sturgeon (Becker, 1983). Before anthropogenic disturbances, distribution of the species included the Mississippi, Missouri, Ohio, and Rio Grande Rivers and their tributaries. Similar to the pallid sturgeon, the shovelnose sturgeon is declining and has been extirpated or is at risk of extirpation from considerable parts of its native range (June, 1977; Moos, 1978; Keenlyne, 1997; Quist and others, 2002). Of the 24 states that comprise the historical range of the shovelnose sturgeon, five list the species as extirpated, and eight list the species as either imperiled or vulnerable (Hesse and Carreirov, 1997; NatureServe, 2005). The World Conservation Union listed the species as "vulnerable" (Surprenaut, 2004). The "vulnerable" assessment reflects a past reduction in species range of 30 percent, and anticipates a further 30 percent reduction in population within the next 10 years, or three generations. Despite these trends in population decline, the shovelnose sturgeon is still harvested commercially or as a sport fish in nine states. In fact, commercial demand for the shovelnose sturgeon has increased because of the increasing demand for caviar exacerbated by the collapse of sturgeon fisheries in Europe and Asia (Williamson, 2003). The closely related, but allopatric shovelnose species from the Mobile River Basin, the Alabama sturgeon (S. suttkusi) is extremely rare and close to extinction (Mayden and Kuhajda, 1996).

The decline of sturgeon populations is a global phenomenon (Birstein, 1993). Habitat alteration, river regulation, pollution, and over-harvest have resulted in the now predictable patterns of decline and localized extirpation of sturgeon across species and geographic areas. Symptomatic of this generalized pattern of decline is poor reproductive success and low, or no, recruitment of wild juveniles to the adult population. Evidence from various monitoring efforts suggests that recruitment of wild pallid sturgeon to the adult population is limited or non-existent throughout most of the Missouri River (U.S. Fish and Wildlife Service, 2000; Jordan, 2006). Some reproduction (larvae were collected and verified) of the endangered pallid sturgeon has been documented in the Lower Missouri River (Louise Mauldin, U.S. Fish and Wildlife Service, oral commun., 2004; Kerry Reeves, University of Missouri, oral commun., 2007) and in the Middle Mississippi River (Hrabik, 2007). Collections of young-of-year pallid sturgeon in the upper Missouri River Basin (Braaten and Fuller, 2005) provide evidence that pallid sturgeon may be spawning in the Yellowstone River or Missouri River below Fort Peck Dam, although juveniles have not been captured there for decades (Jordan,
2006). In contrast, the closely-related shovelnose sturgeon is reproducing, and recruitment is occurring in the Missouri River (Moos, 1978; Keenlyne, 1997).

Despite evidence of substantial decline, the shovelnose sturgeon remains relatively common in the Lower Missouri and Mississippi Rivers (Becker, 1983). The persistence and resiliency of the shovelnose sturgeon in comparison to the pallid sturgeon may be partly because of its earlier maturity, lower trophic status, and adaptability to a broader range of environmental conditions. The shovelnose sturgeon matures earlier and attains a smaller maximum size than the pallid sturgeon (Keenlyne and Jenkins, 1993). The smaller shovelnose sturgeon primarily subsists on invertebrates, whereas the larger pallid sturgeon becomes piscivorous relatively early in life (Modde and Schmulbach, 1977; Keenlyne, 1997; Carlson and others, 1985). Pallid sturgeon also are highly adapted to large, turbid, riverine environments, and are believed to not use tributaries or clear-water riverine habitats that are frequented by shovelnose sturgeon (Mayden and Kuhajda, 1997). Despite these differences, the morphological, physiological, and genetic similarity between the taxa clearly indicates that these two sympatric species are closely related (Bailey and Cross, 1954; Campton and others, 2000; Simons and others, 2001; Snyder, 2002).

This report and the model developed within focus on the pallid and shovelnose sturgeon, hereafter referred to as Scaphirhynchus in this report.

\section{Purpose and Scope}

The purpose of this report is to introduce a conceptual life-history model (hereafter referred to as model in this report) of the factors that affect reproduction, growth, and survival of Scaphirhynchus sturgeons. The model is intended as a tool to organize, visualize, and prioritize hypotheses relating to how the complex life history of Scaphirhynchus sturgeons relates to the spatial and temporal complexity of large interjurisdictional rivers. The model and its primary components are described, with some emphasis on specific components to illustrate its hierarchical nature.

The model was developed to provide a framework to help guide scientific approaches needed for a better understanding of the ecological requirements of the pallid sturgeon. Although there is some emphasis on delineating how Scaphirhynchus sturgeon ecology relates to river management variables, it also attempts to include all conceivable conditions and processes that might affect Scaphirhynchus sturgeon ecology to make it applicable to a wide range of research hypotheses. Within this context, pallid sturgeon ecological needs can be explored as they relate to species recovery efforts, as well as the broader aspects of river-system management. It was designed to be adaptable for communication and as a science planning tool. The model is intended to be dynamic and responsive to new information and changes in river management, thereby provid- 
ing stakeholders, managers, and researchers with an improved understanding of tradeoffs among management alternatives.

\section{Basis for the Conceptual Life-History Model}

Multiple abiotic and biotic factors have been proposed as critical for maintaining healthy populations of Scaphirhynchus sturgeons (fig. 1). Among the abiotic factors, physical factors (for example, hydrologic cues, temperature, turbidity, depth, and velocity) and features of in-channel habitat are believed to be important (U.S. Fish and Wildlife Service, 2000, 2003). Biotic (nutrition, competition, predation, productivity) and abiotic chemical (for example, water quality) factors also are important contributors to reproductive success and survival. An understanding of how all these factors alone and combined affect recruitment of Scaphirhynchus to each life stage is needed to provide rigorous and defensible information for use by all stakeholders to resolve issues surrounding pallid sturgeon recovery actions. This need was the motivation for development of the conceptual life-history model.

This model also was designed to provide the framework for a quantitative population forecasting model to predict future population size and distribution of pallid and shovelnose sturgeon on the Missouri River. The population forecasting modeling effort will synthesize extant and anticipated data from research studies and the Missouri River Recovery fish monitoring programs (Pallid Sturgeon Population Assessment Program, Habitat Assessment and Monitoring Program, and Bank Stabilization and Navigation Project Mitigation Program) to describe population status, probable bottlenecks, and additional information needs.

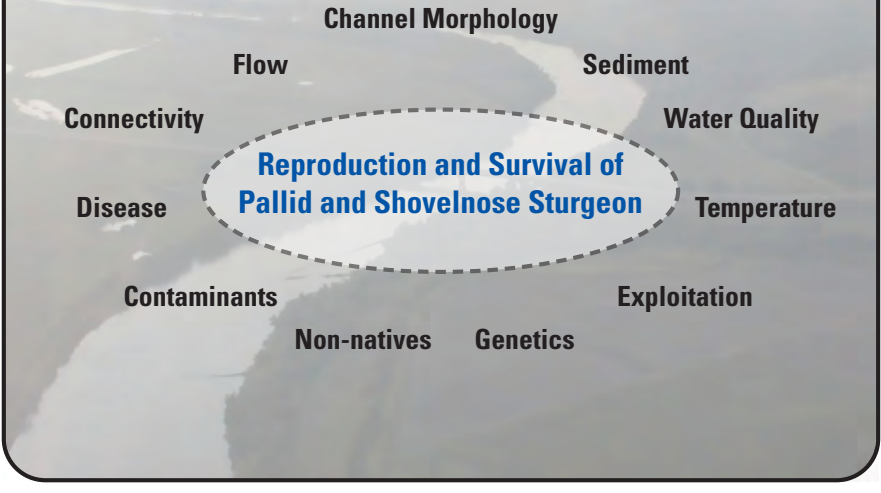

Figure 1. Factors that may affect reproduction and survival of sturgeons.

\section{Structure of the Conceptual Life- History Model}

The conceptual life-history model for Scaphirhynchus sturgeon is consistent with-and could be incorporated as a submodel within - a system-wide, adaptive ecosystem management model for the Missouri and/or Mississippi River Basins. Such a comprehensive ecosystem model could include similar life-history submodels for other key species, such as the piping plover (Charadrius melodus) and least tern (Sternula antillarum), and/or it could incorporate socio-economic benefits.

The life history of sturgeon (fig. 2) is divided into distinct life stages (boxes) with transitions from one life stage to the next (diamonds). The direction of sturgeon development is identified by arrows. Numerous conditions and processes determine whether or not individual sturgeon complete the transition from one life-stage to the next (ovals). In refining the model, lines of varying thickness could be drawn to indicate the importance of each connection among conditions and processes.

The spatial extent of the model is intended to capture scales relevant to individuals and the population. Because sturgeon in large rivers may move long distances during the course of their lives, the model illustrates the potential for sturgeon to use different parts of the river mainstem, or its tributaries, in specific ways during different life stages. The model also can accommodate fine-scale, three-dimensional models of habitat use and availability, and fish behavior during specific life stages, nested within the broader geographic extent. The model is designed to be dynamic, so it can be refined as new information is attained. Consequently, other important conditions, processes, and connections may be present that have not yet been identified in the current model, but will need to be incorporated in the future as more information is collected on the ecology of Scaphirhynchus sturgeon.

Our current (2007) state of knowledge is insufficient to prioritize the relative importance of the various connections to reproduction and survival. The model is intended as a starting framework to build the necessary scientific foundation. We anticipate that the conceptual model will be refined iteratively as scientists work collaboratively to share knowledge. It also may be useful to the broader community of Missouri River managers, stakeholders, and scientists to ensure that the Scaphirhynchus sturgeon framework is consistent with conceptual models of other priority management species, and with a comprehensive, ecosystem-level adaptive management model.

\section{Processes and Conditions Controlling Life-Stage Transitions}

The following section discusses the conceptual model (fig. 2) by life-stage transition. For each life-stage transition, a 


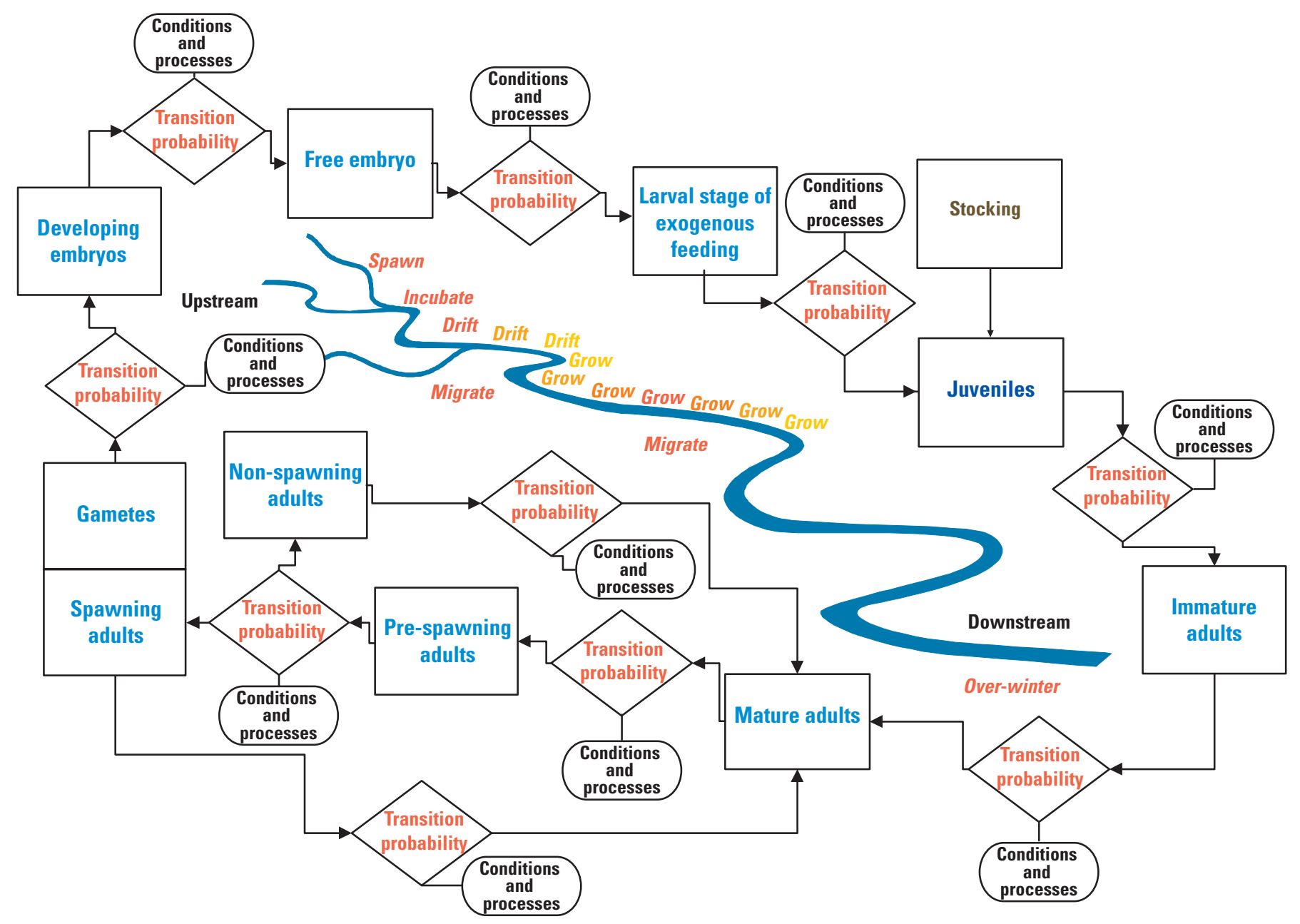

EXPLANATION
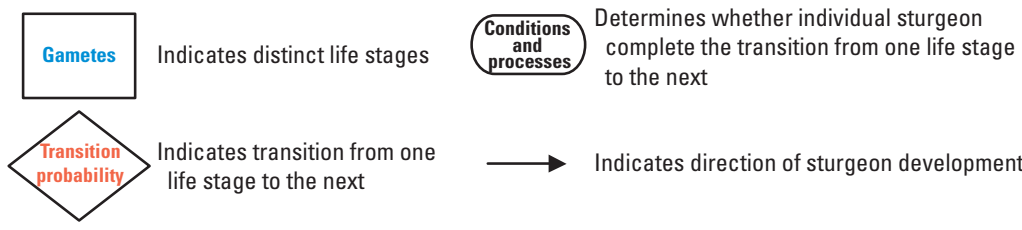

Figure 2. Conceptual model of Scaphirhynchus sturgeon life history.

submodel is presented based on a general understanding of the biological transition. For each transition, a list of hypothesized processes and conditions (fig. 3) that may affect the probability of a successful transition is presented.

The two primary categories of processes identified as affecting the transition between life stages for Scaphirhynchus sturgeons were direct mortality through human activities and/or non-human predators and rate-affecting processes that affect survival, growth, and development (especially of functionally reproductive individuals) (white rectangles in fig. 3). Human activities identified as contributing to direct mortality include human predation in the form of fishing, dredging, boating, and entrainment by water intakes (represented by red rectangles in fig. 3). The groups of predators identified as contributing to direct mortality include native and non-native fishes, and non-fish predators (for example, macroinvertebrates, birds, also represented by red rectangles in fig. 3). The rate-affecting processes identified as affecting survival, growth, and development include habitat, contaminants, disease, prey availability, and competition (represented by white wavy rectangles in fig. 3). Competitors are represented by the same groups identified as predators, but not necessarily the same species. The condition factors considered as determinants of the importance of rate-affecting processes on survival, growth, and development include biotic (represented by green rectangles in fig. 3) and abiotic (represented by blue rectangles in fig. 3) factors. The biotic conditions identified include the food web and the nutrients cycled within it, competition, and 

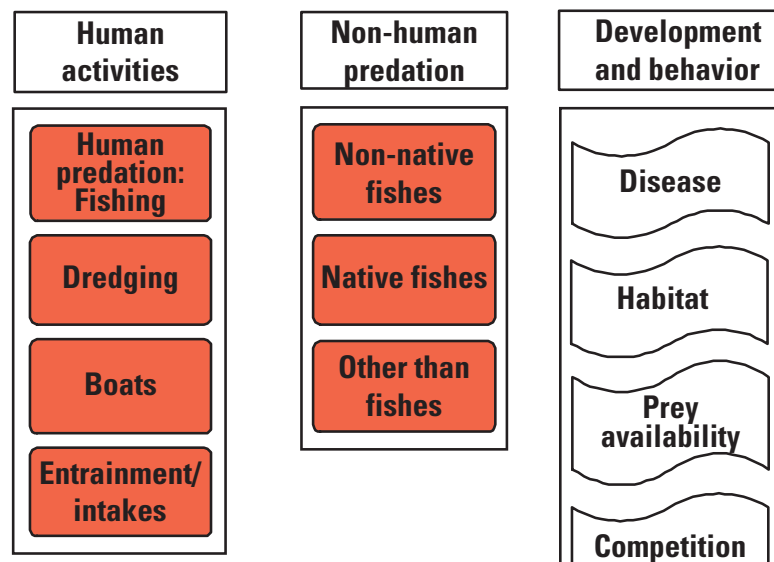

Condition factors

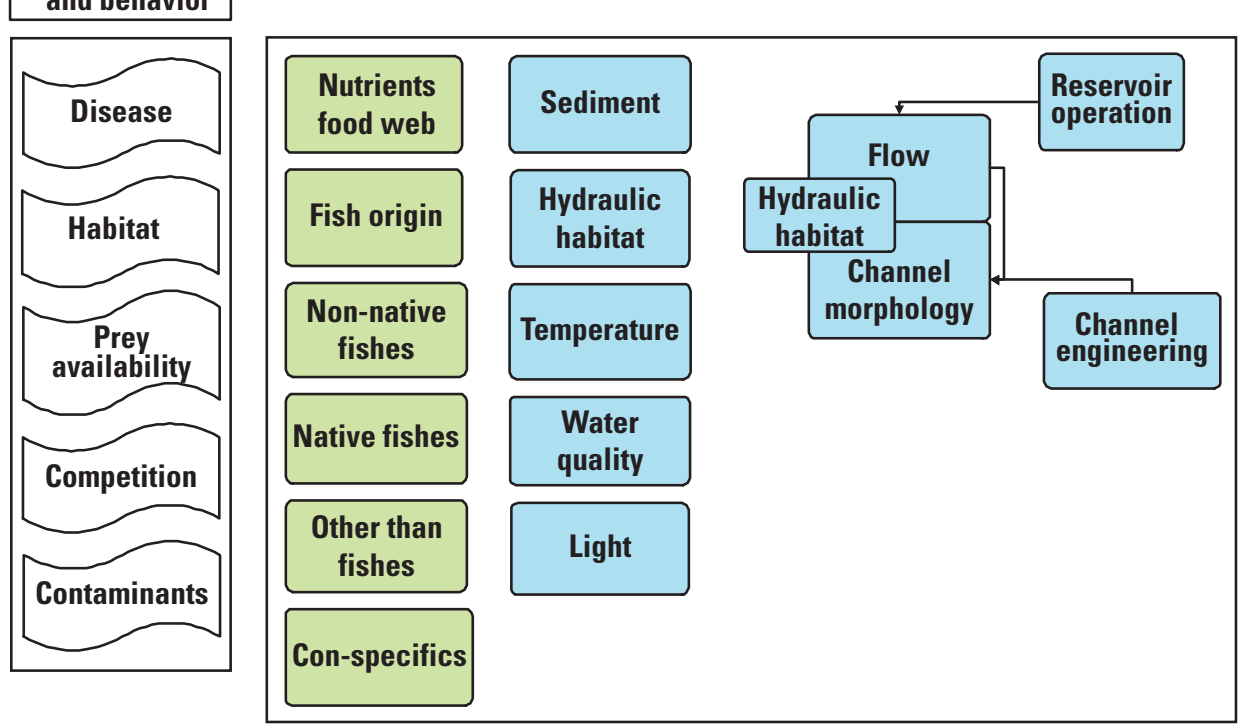

EXPLANATION
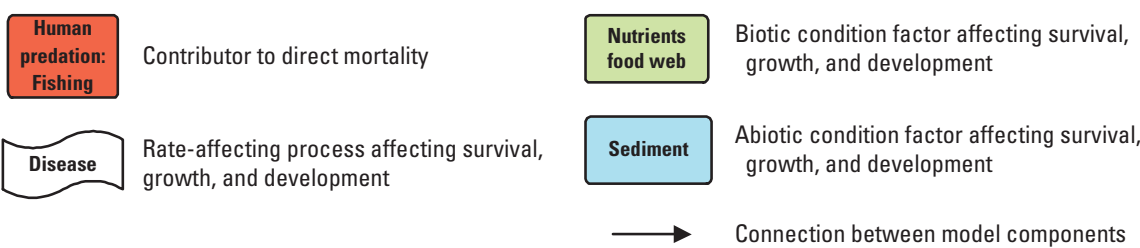

Figure 3. Symbols and labels used in submodels of Scaphirhynchus sturgeon conceptual model.

genetic origin of the sturgeon. The abiotic conditions identified include light, temperature, sediment, water quality, and hydraulic habitat. Hydraulic habitat is defined as the result of the flow and channel morphology, both of which are affected directly by management.

For the various life-stage submodels, the processes and conditions identified are similar. The consistency among submodels is because of the general nature of the categories identified, and the fact that each submodel represents the same genus. As the conceptual model is refined, it is likely that submodels will be altered to reflect dominance of different processes for different life stages. Variations of the model could be developed for different geographic areas or pallid sturgeon management units.

\section{Mature to Pre-Spawning to Spawning Adult}

Existing evidence suggests that there is minimal to no recruitment of young pallid sturgeon to the adult population throughout the Missouri River Basin (U.S. Fish and Wildlife Service, 2000; Jordan, 2006). A suggested cause for recruitment failure is the lack of successful reproduction because of absent or improper environmental cues (Quist and others, 2004).
The timing of spawning for fish that spawn seasonally generally is believed to have evolved in synchrony with the seasonal hydrologic and environmental conditions that provide the best possible chance of survival for offspring (Balon, 1975; Munro and others, 1990). Most North American sturgeon spawn between the spring equinox and summer solstice, with a spawning run peak often coinciding with the annual peak flow (Cech and Doroshov, 2004). Historically, North American sturgeon have been reported to spawn from spring to mid-summer, depending on latitude and water temperature [lake sturgeon (Acipenser fulvescens), Eddy and Surber, 1947; pallid sturgeon, Forbes and Richardson, 1920; shovelnose sturgeon, Christenson, 1975; green sturgeon (Acipenser medirostris), Van Eenennam and others, 2005; shortnose sturgeon (Acipenser brevirostrum), Taubert, 1980; Atlantic sturgeon (Acipenser oxyrhynchus), Van Enennaam and others, 1996; gulf sturgeon (Acipenser oxyrhynchus desotoi), Fox and others, 2000]. During the spawning season, specific environmental cues can trigger or be associated with the physiological changes in the fish that results in spawning activity: migration, aggregation, courtship, ovulation, oviposition, and fertilization (Rankin and others, 1983). Although the biochemical, physiological, and behavioral events generally are synchronized, they 
can become decoupled and the result is unsuccessful spawning (Dettlaff and others, 1993).

The effect of hydrology on spawning has not been described for shovelnose or pallid sturgeon, but fishery biologists speculate that spawning runs are similarly dependent on river flow (Becker, 1983; Keenlyne and Jenkins, 1993; U.S. Fish and Wildlife Service, 2000). Migrations of shovelnose sturgeon into smaller streams, presumably for spawning, have been reported when sufficient water is available (Becker, 1983); however, similar use of small tributaries by pallid sturgeon has not been documented. The spawning behavior sequence from migration and aggregation at the spawning site through egg deposition has not been documented for the shovelnose or pallid sturgeon. The timing, periodicity, and location of spawning events in relation to the substrate and overlying water conditions (temperature, turbidity, flow, and velocity) also are unknown. This information is critical when determining how to improve availability of optimal spawning habitat and by designing experimental flows intended to promote reproduction and survival of young sturgeon.

Spawning areas of other North American sturgeon species most often are characterized by coarse or hard substrates. White sturgeon (Acipenser transmontanus, Scott and Crossman, 1973; Parsley and others, 2002); green sturgeon (A. medirostris, Houston, 1988); shortnose sturgeon (A. brevirostrum, Taubert, 1980; Buckley and Kynard, 1985); Atlantic sturgeon (A. oxyrinchus oxyrinchus, Scott and Crossman, 1973); gulf sturgeon (A. oxyrinchus desotoi, Fox and others, 2000); and lake sturgeon (A. fulvescens, Scott and Crossman, 1973; LaHaye and others, 1992; Bruch and Binkowski, 2002) all spawn primarily over gravel, cobble, boulder or bedrock. Limited data exist about the substrate preferences of spawning pallid and shovelnose sturgeon. Pallid and shovelnose sturgeon are assumed to spawn in river current over coarse substrate in, or adjacent to, the main river channel (Becker, 1983; Mayden and Kuhajda, 1997). Eggs of most sturgeon species are broadcast over spawning areas, become adhesive soon after release, and attach to the substrate until hatch (Breder and Rosen, 1966).

Sturgeons differ from most teleosts by their late puberty and biennial or longer ovarian cycles (Dettlaff and others, 1993). In fishes, gametogenesis and reproduction are controlled primarily by a number of different hormones (Sullivan and others, 1997). Likewise, these hormones are in turn modulated by environmental and biological stimuli (Rosenblum and others, 1987). Thus, the maturation of gametes and their release is the end result of a cascade of physiological events partially under endogenous biological controls, but also controlled by environmental conditions (Dettlaff and others, 1993; fig. 4).

As with many temperate species, sturgeon reproduction follows seasonal cycles (Cech and Doroshov, 2004). It is widely believed that the pineal organ, through synthesis of melatonin by its photoreceptors, triggers and perhaps synchronizes the biochemical, physiological, and behav- ioral aspects of reproduction in fishes (Rankin and others, 1983). In addition to photoperiod, reproduction in sturgeon is controlled by water temperature (Dettlaff and others, 1993). Most of the enzymatic biochemical processes during gametogenesis and gamete release are temperature sensitive. In addition to these variables, other environmental conditions that may be important in gamete maturation and release include substrate, flow, turbidity, numbers of fish present, behavior of conspecifics, and presence of pheromones (Rankin and others, 1983).

A similar set of conditions and processes that determine the probability of a sturgeon transitioning from a mature adult to pre-spawning adult (fig. 4) also determine the probability of whether or not a pre-spawning adult spawns, and whether or not the non-spawners and spawners successfully survive and transition back into the pool of adult sturgeon to spawn again (figs. 2 and 4). Although the conditions and processes that regulate these transitions may be similar, the importance of each probably is different for each transition.

Factors that may play a role in limiting spawning activity for sturgeon could include non-synchronized hydrology, temperature, migration impediments, lack of spawning substrate, inadequate numbers of reproductive adults, hybridization with closely related sympatric species, predation, and contaminants. Unfortunately, the exact spawning location and the relative suitability of spawning conditions for these sturgeon species are not known. In addition, spawning behavior of both species is not well documented, and scientists have only begun to describe the reproductive physiology (Wildhaber and others, 2005, 2006).

\section{Spawning Adults with Viable Gametes to Developing Embryos}

The production of embryos that can develop normally and hatch requires conditions suitable for egg fertilization and minimization of direct loss of eggs (fig. 5). Because this life-stage transition includes spawning adults at the point of release of gametes and eggs at fertilization, the processes and conditions critical to it are a combination of those critical during the previous reproductive stage and the developing embryo to free embryo life-stage transitions. Successful transition through this stage is dependent on healthy viable gametes and environmental conditions, especially temperature and the presence or absence of egg predators (Dettlaff and others, 1993).

\section{Developing Embryo to Free Embryo}

Early life stages of riverine fishes tend to be the most sensitive to environmental stressors (Scheimer and others, 2001). Fluctuations in water temperature, reduced oxygen, poor egg quality, and contaminant exposure are known to result in abnormal development and high mortality in this life stage of sturgeon (Dettlaff and others, 1993; fig. 6). 


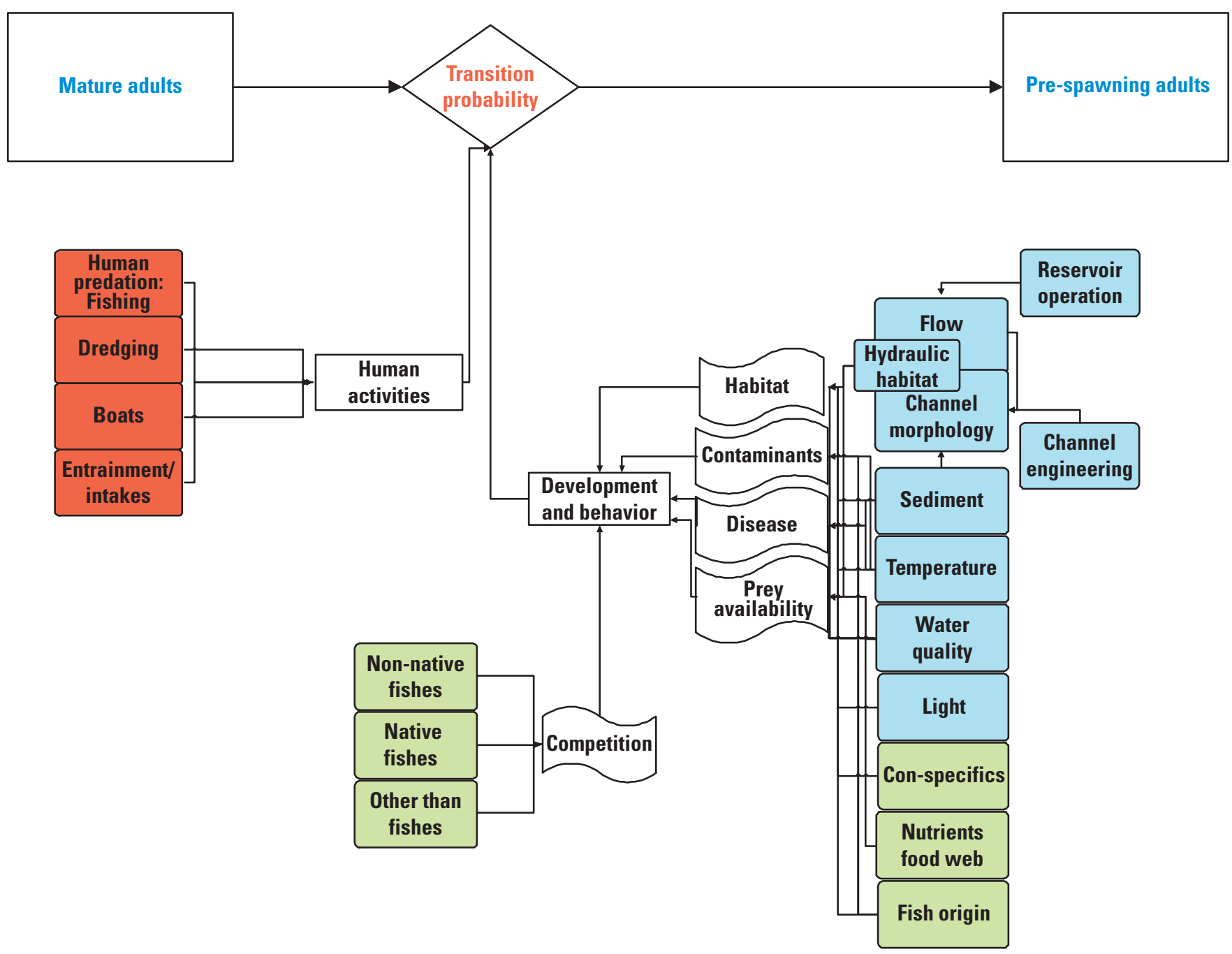

EXPLANATION

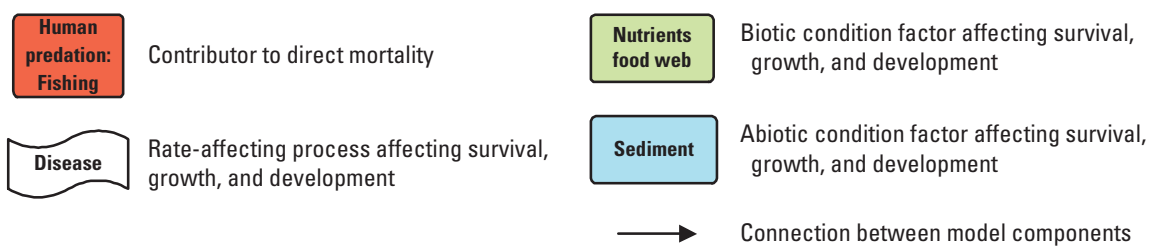

Figure 4. Submodel for the transition from mature to pre-spawning adult in the Scaphirhynchus sturgeon life-history conceptual model.

Temperature and dissolved oxygen are primary environmental factors on the rate of embryo development (Jobling, 1995). Oxygen requirements of eggs generally increase with development, being greatest at hatch. Adhesive sturgeon eggs may be susceptible to smothering by fine particulates in an extremely turbid environment. Maternal contribution to the egg determines the quality of the nutritional reserves in the egg, and ambient temperature and oxygen determine the rate at which the yolk nutrition is used (Dettlaff and others, 1993). Sturgeon embryos must have the necessary nutritional sources for complete development, but also have sufficient yolk reserves beyond hatch until exogenous feeding begins. Chemical contaminants could be of concern in the large rivers used by Scaphyrinchus sturgeon (Ruelle and Keenlyne, 1993; Harsbarger and others, 2000). Early life stages generally are most sensitive to contaminants with exposure occurring during maternal yolk deposition and/or during incubation through contact with water or sediments. Although shovelnose and pallid sturgeon have been successfully reared in captivity, few data exist on their tolerance levels to spe- 

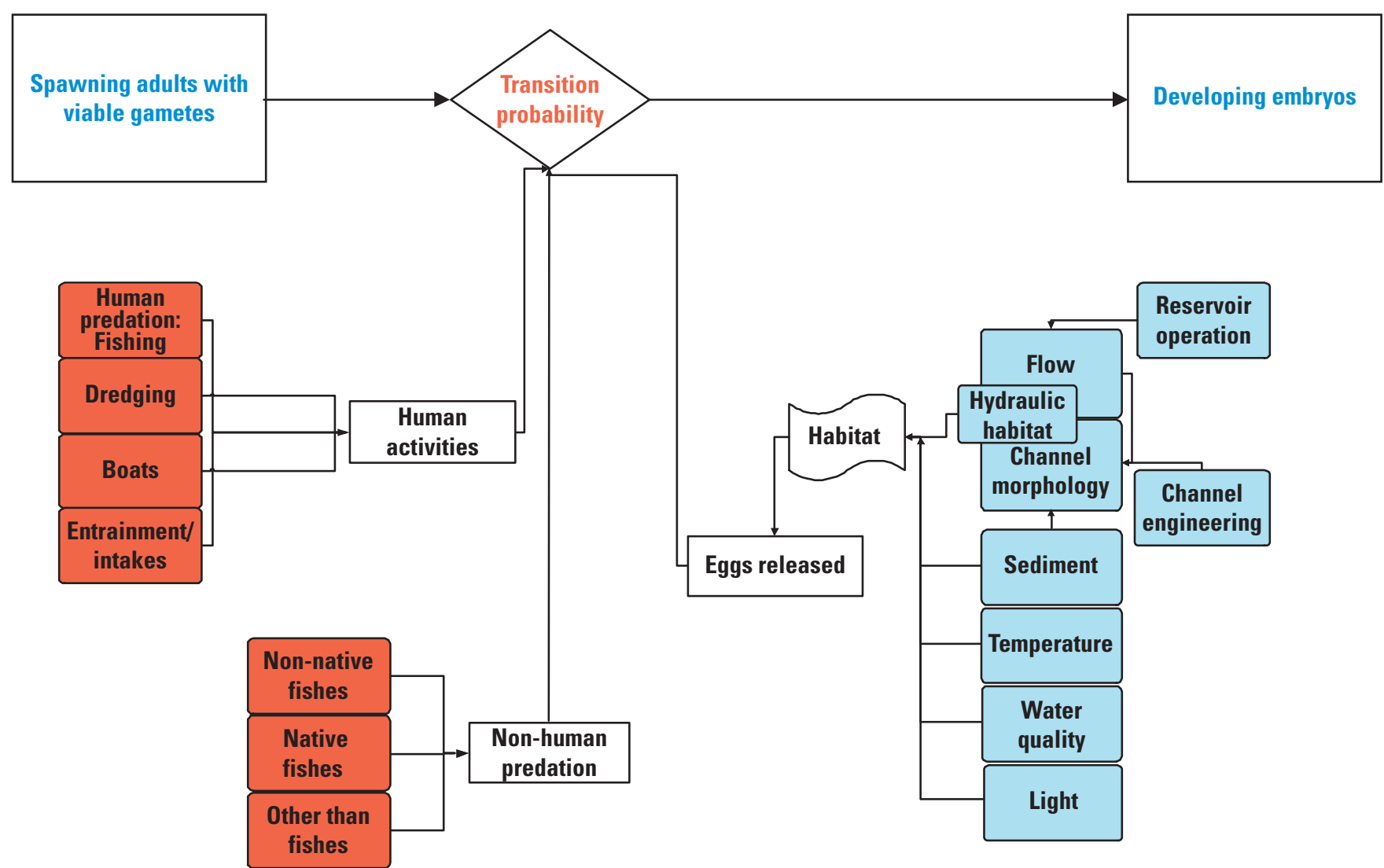

EXPLANATION

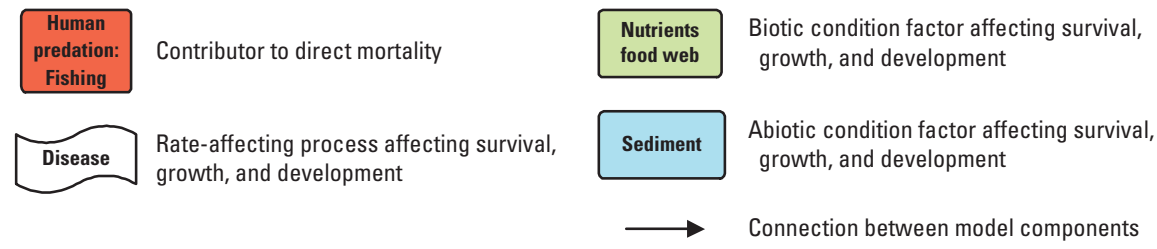

Figure 5. Submodel for the transition from spawning adults with viable gametes to developing embryos in the Scaphirhynchus sturgeon life-history conceptual model.

cific environmental stressors. Given the documented waterquality changes reported for many locations along the Lower Missouri River (Galat and others, 2001; Hesse and others, 1989), it is possible that a bottleneck to recruitment will occur at this stage of sturgeon life history.

\section{Free Embryo to Larval Stage of Exogenous Feeding}

Limited spawning success and recruitment could be bottlenecks to self sustaining pallid sturgeon populations. The larval stage often functions as a recruitment bottleneck for fish because of decreased mobility and sensory ability, and increased vulnerability to anthropogenic environmental alteration (Scheidegger and Bain, 1995; Humphries and others, 2002). Although documentation of spawning by pallid sturgeon is a critical first step towards assessing population status and recovery, successful spawning does not ensure successful recruitment to the juvenile or adult life stages; rather, biotic and abiotic factors operating during the post-hatch life stages may establish recruitment bottlenecks that cause high mortality during the posthatch life stage (Dettlaff and others 1993; fig. 7). Limited numbers of larval sturgeon are collected from the Mississippi and Missouri Rivers (Louise Mauldin, U.S. Fish and Wildlife Service, oral commun., 2004; Kerry Reeves, University of Missouri, oral commun., 2007; Hrabik, 2007).

This suggests one or more of the following factors may be responsible: lack of successful spawning, low recruitment, high mortality, ineffective sampling methods, inadequate sampling of drift and settling locations, or rapid dispersal 


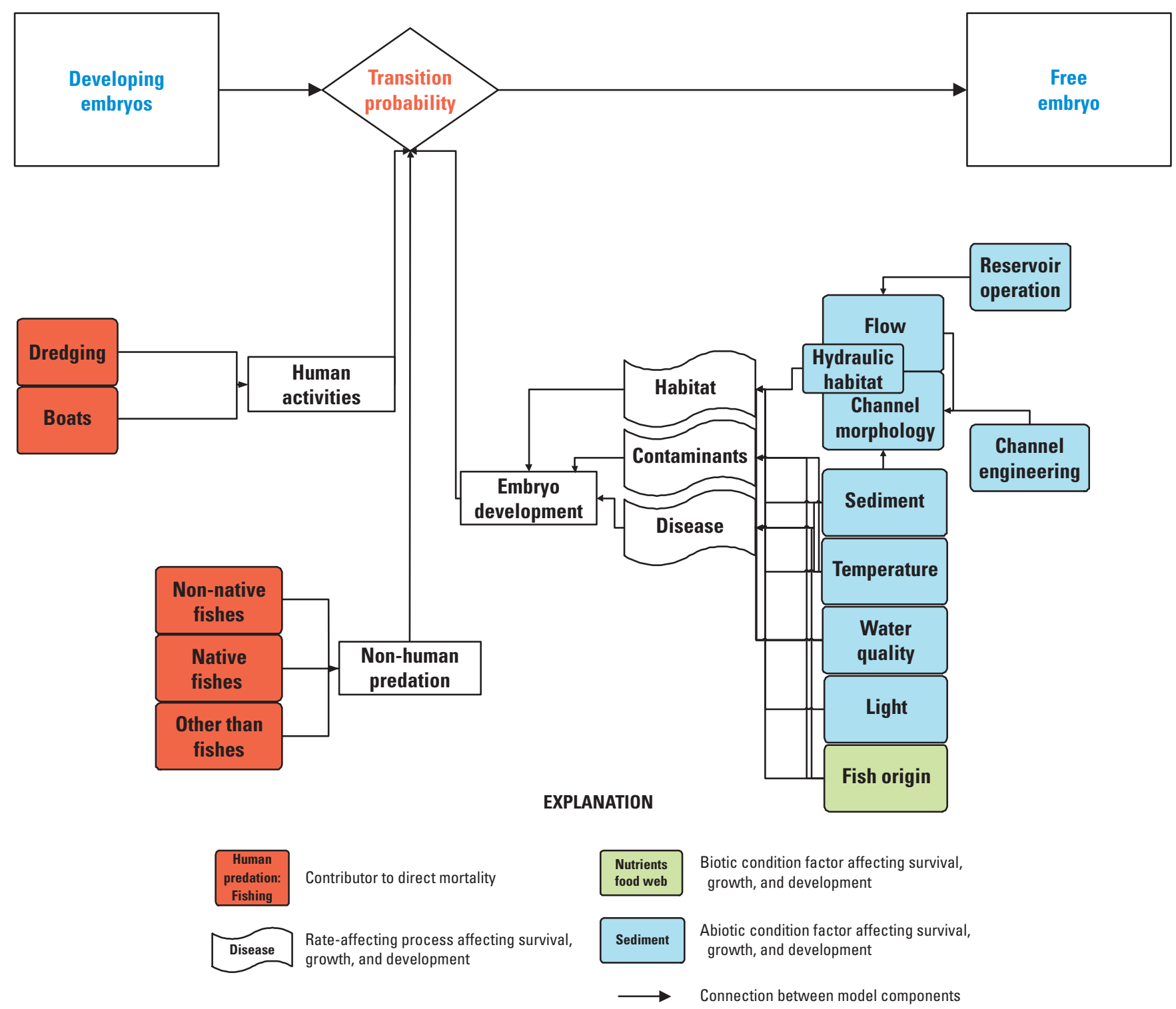

Figure 6. Submodel for the transition from developing embryo to free embryo in the Scaphirhynchus sturgeon life-history conceptual model.

and washout of sturgeon larvae in the Missouri and Mississippi Rivers. Given the sensitivity of the post-hatch life stage to mortality, it is important to identify determinants of post-hatch survival in pallid sturgeon.

Few data are available on the post-hatch life stage of pallid and shovelnose sturgeon. Post-hatch life stage spans from hatching to the initiation of feeding (hereafter referred to as post-hatch larvae in this report). Larval sturgeon raised at $17-18{ }^{\circ} \mathrm{C}$ (degrees Celsius) initiate feeding at around 10 days (Dettlaff and others, 1993). Initiation of feeding probably would occur before day 10 at warmer water temperatures. Pallid sturgeon larvae in hatcheries initiate feeding between days 4 and 6 post-hatch (Herb Bollig, U.S. Fish and Wildlife Service, oral commun., 2006). In natural settings, shovelnose sturgeon initiate exogenous feeding at about $16 \mathrm{~mm}$ (millimeters) long, and feed on dipterans and emphemeropterans (Braaten and others, 2007). After hatching, larval pallid and shovelnose sturgeon in laboratory studies drift for up to 13 days (Kynard and others, 2002). The prolonged drift period of larval sturgeon necessitates a similarly long stretch of freeflowing water to complete the ontogenetic drift cycle. Larvae are suspected to be intolerant of sediments that deposit in river-reservoir transition zones; therefore, a recruitment bottleneck for sturgeon in riverine reaches terminated by a reservoir may be related to insufficient length of free-flowing water. Initiation of feeding on or about day 10, coupled with the finding that sturgeon start using benthic habitats on or about day 8 , indicates occupation of benthic habitats is food related (Dettlaff and others, 1993). 


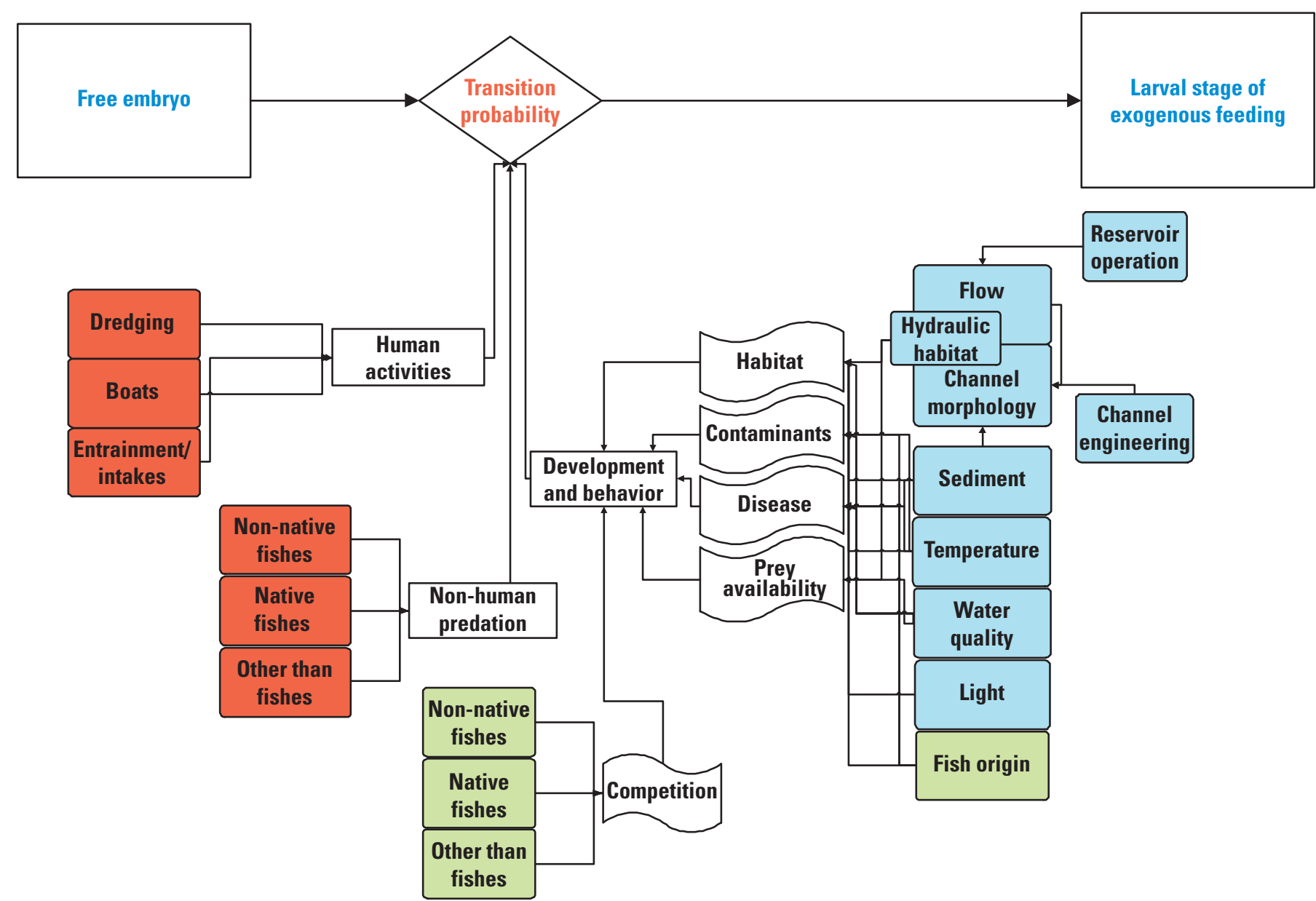

EXPLANATION

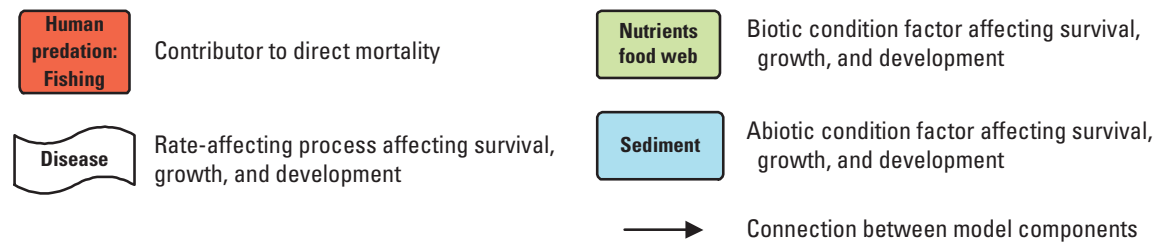

Figure 7. Submodel for the transition from free embryo to larval stage of exogenous feeding in the Scaphirhynchus sturgeon lifehistory conceptual model.

\section{Larval Stage of Exogenous Feeding to Juveniles}

Population viability of Scaphirhynchus sturgeons through the larval feeding stage hinges on elucidating the primary natural and anthropogenic factors that contribute to survival during this period (fig. 8). The stage when larval fish begin feeding often is called the "critical period" because they are extremely susceptible to mortality if food of the proper size and nutritional value is not available within a short time (Gisbert and Williot, 1997; Deng and others, 2003; Gisbert and Doroshov, 2003). Lack of food during the transition from endogenous to exogenous feeding has deleterious effects on the sturgeon digestive tract (Gisbert and Doroshov, 2003) that may diminish growth and survival (Gisbert and Williot, 1997; Gisbert and Doroshov, 2003). Similarly, restricted availability and limited intake of food during the first feeding life stage may suppress growth (Deng and others, 2003).

Planktonic larvae must be transported by river currents to appropriate habitats where nutritional food is abundant and environmental conditions are benign. Longitudinal fragmentation by reservoirs, temperature reductions below dams, channelization, and bank stabilization collectively may have altered developmental rates and natural drift patterns, increased transport distances, and reduced in-channel retention and food production.

Predation and competition also must be low for larvae to survive to the juvenile life stage. Because the feeding larval 


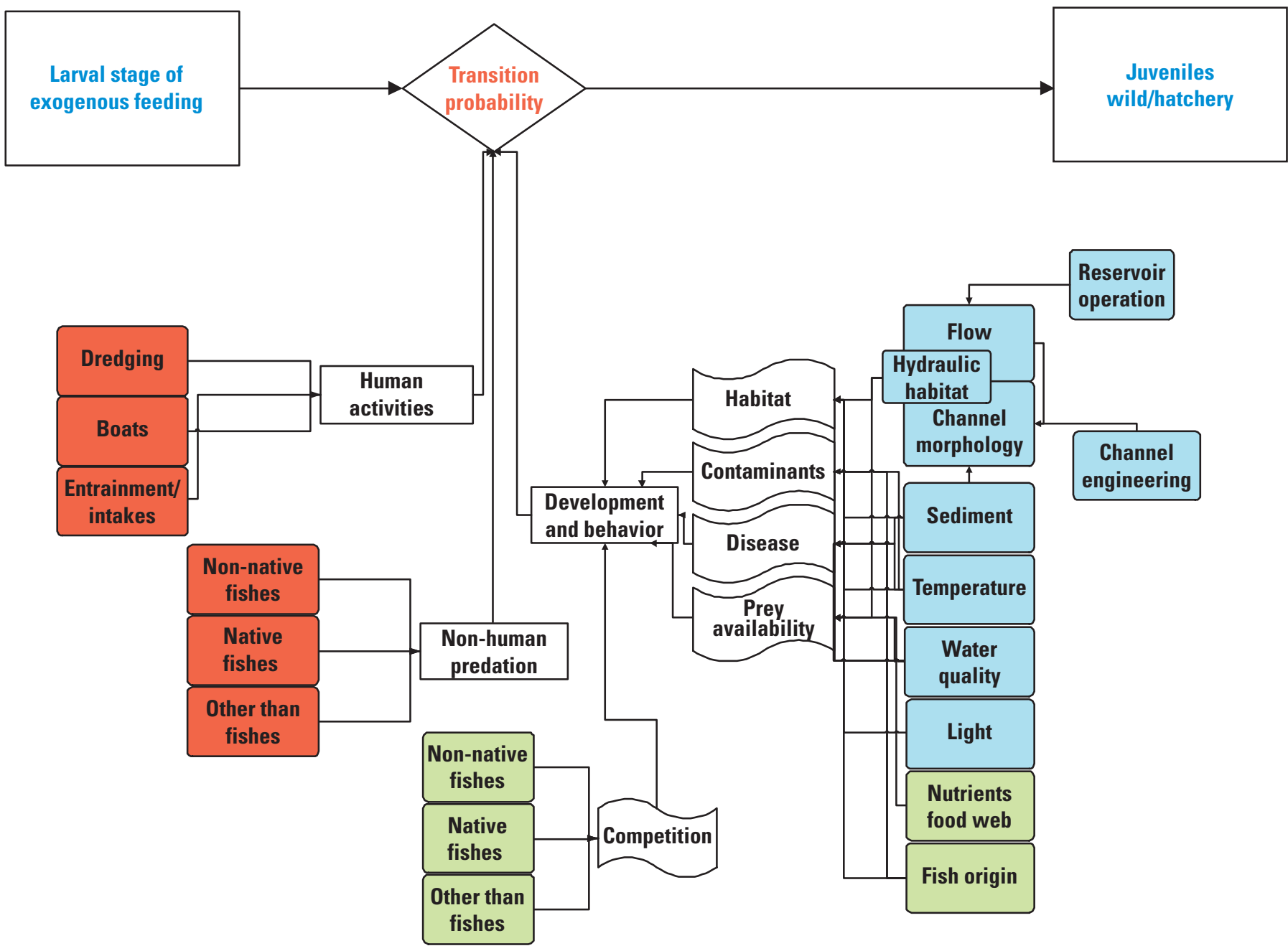

EXPLANATION

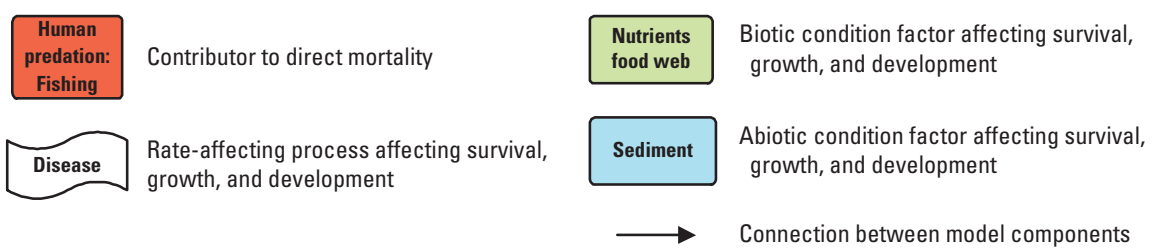

Figure 8. Submodel for the transition from larval stage of exogenous feeding to juveniles in the Scaphirhynchus sturgeon life-history conceptual model.

sturgeon are small, they are particularly susceptible to mortality from predation. The Lower Missouri River water clarity has increased since impoundment; which may have increased predation risk to small sturgeons that historically relied on the river's high turbidity as cover from sight-feeding piscivores fishes such as sauger (Sander canadense), goldeye (Hiodon alosoides), walleye (Sander vitreus vitreus), and smallmouth bass (Micropterus dolomieu) (Hesse and others, 1989). Most of the other more than 60 species of the Missouri's riverine fishes feed on zooplankton at the larval stage, and several juveniles and adults of native fishes (for example, paddlefish) and non-native fishes [for example, bighead carp (Hypophthalmichthys nobilis)] also feed primarily on zooplankton (Berry and others, 2005; Pflieger, 1997), all of which may be directly competing with sturgeon larvae for food resources.

\section{Juvenile to Immature Adult}

At age 1, shovelnose sturgeon and pallid sturgeon closely resemble adults. Juvenile and adult sturgeon have few natural 
predators and annual mortality is thought to be relatively low (Quist and others, 2002). The factors most likely to affect sturgeon of this age class are human exploitation, availability of food resources, habitat quality, and competition (fig. 9).

Because of their life-history traits (late maturity and infrequent spawning) shovelnose and pallid sturgeon are extremely susceptible to impacts of overharvest (Bajer and Wildhaber, 2007; Quist and others, 2002). Many species of sturgeon have yet to recover from previous episodes of over-exploitation (Williams and others, 1989).

Pallid sturgeon, like shovelnose sturgeon, primarily consume invertebrates when less than 1-year old (Becker, 1983; Modde and Schmulbach, 1977), but unlike shovelnose sturgeon, they primarily are piscivorous juveniles and adults (Gerrity and others, 2006). Previous field collections of shovelnose and pallid sturgeon adults indicate that part of their diets are made up of benthic macroinvertebrates (Modde and Schmulbach, 1977; Keenlyne, 1997; Carlson and others, 1985; Gerrity and others, 2006). The diet of the shovelnose sturgeon is comprised almost exclusively of macroinvertebrates (Gerrity and others, 2006). Recent evidence (George and others, 2007; Gerrity and others, 2006) indicates that several Macrhybopsis chubs are important items in diets of pallid sturgeon; populations of several of these chub species have declined. (Pflieger and Grace, 1987; Hesse and others, 1989; Galat and others, 2005).

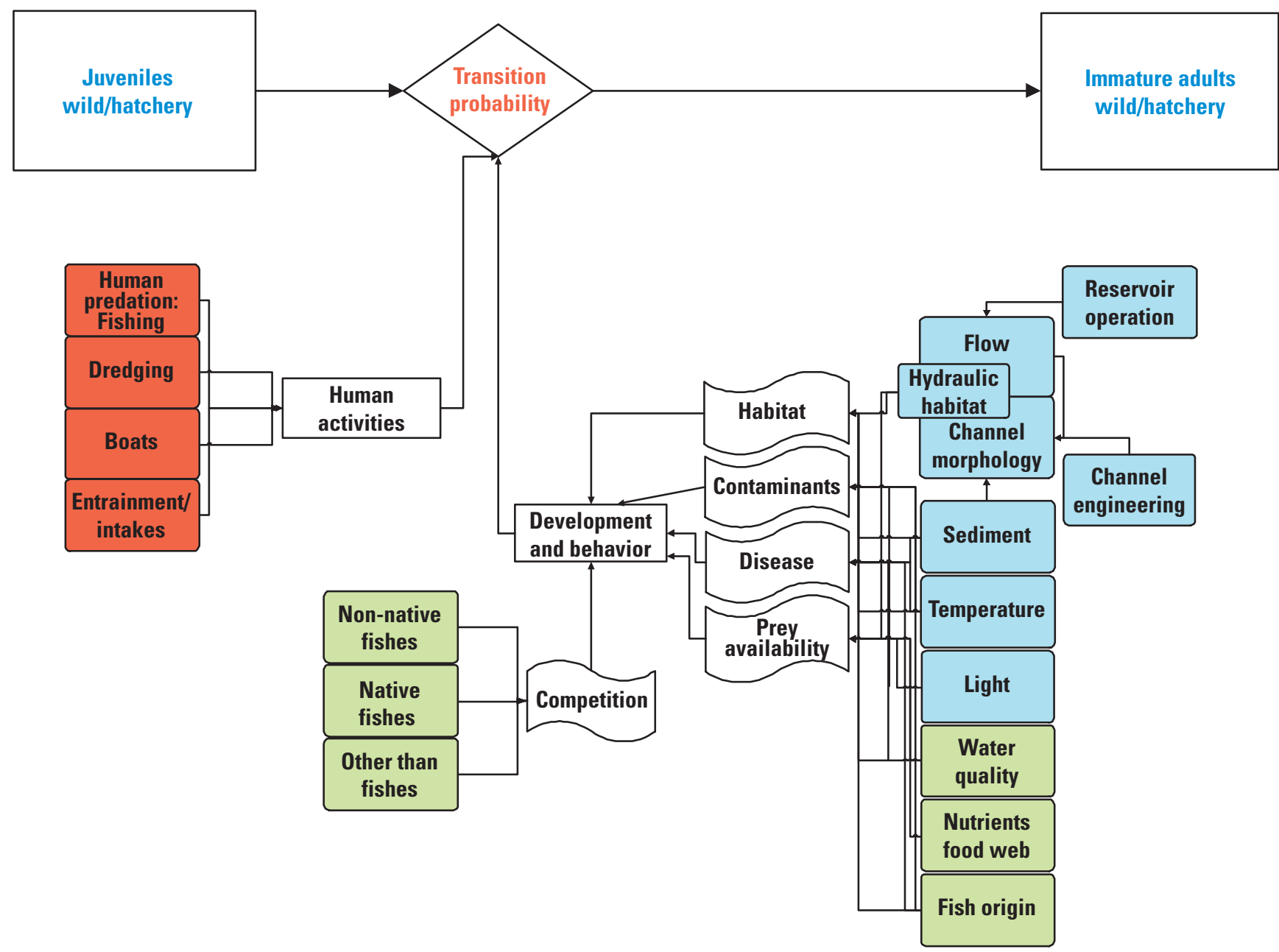

EXPLANATION
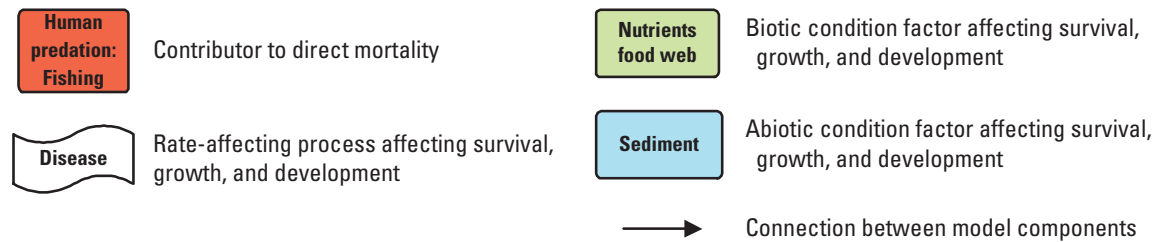

Figure 9. Submodel for the transition from juvenile to immature adult in the Scaphirhynchus sturgeon life-history conceptual model. 
The species composition of prey fishes in the river has changed since the 1940s (Berry and others, 2005; Hesse and others, 1989). Although gizzard shad (Dorosoma cepedianum) are habitat generalists, (Leslie and Timmins 1998a, 1998b; Galat and others, 2005), their spawning in rivers is believed to occur in shallow, slow-velocity habitats such as backwaters and main-channel borders (Scott and Nielsen, 1989). Adult gizzard shad are detritivores and periphyton grazers that strongly affect sediments and nutrients within the water column of lakes (Vanni, 1996). This led Arrington and Winemiller (2003) to speculate that gizzard shad may markedly affect ecosystem dynamics in lowland rivers where they are abundant. It is unknown if such changes in preyfish species composition may have negatively affected the pallid sturgeon.

Information on growth rates of shovelnose and pallid sturgeon in the wild is limited because of the lack of effective age and growth methodologies; however, understanding the age and growth of shovelnose and pallid sturgeon is essential for assessing population status and forecasting population trends. Critical to any fish species recruitment is overwinter survival (Hurst and Conover, 1998). Availability of nonlethal temperatures and adequate quantity and quality of food resources is critical for overwintering survival and recruitment of any temperate fish species. No information is available on the conditions necessary for overwinter survival of shovelnose and pallid sturgeon.

Whereas there are some limited data collected by telemetry on temperature, water velocity, turbidity, and substrate use by pallid sturgeon in the Missouri River (Bramblett and White, 2001), it cannot be assumed that the preferred habitat is available to the fish. Most of the Lower Missouri River has been forced into a single channel by structures meant to improve navigation, and the waters of this channel are well mixed. Only in the case of tributaries and long chutes and side channels do temperature and water quality of moving water differ significantly from that present in the thalweg of the Missouri (Galat and others, 2001). If pallid sturgeon need to select temperature and water quality regimes that vary from that present in the thalweg, the options in the altered river are extremely limited.

Shovelnose and pallid sturgeon are well adapted to bottom habitats of large rivers with swift, turbid, free-flowing water; however, the pallid sturgeon do not use small tributaries or clear-water riverine habitats that are frequented by shovelnose sturgeon (Mayden and Kuhajda, 1997). Bramblett and White (2001) suggest that pallid sturgeon exhibit some selectivity for sand bottom that may be affected by temperature and turbidity. Since sand is the primary substrate present in the Missouri River, it is not clear whether or not the temperature, turbidity, and substrate associations detected in the field are the result of habitat choice, or the predominance of those habitats. Furthermore, since there is no information on habitat associations or habitat choice of shovelnose and pallid sturgeon before alterations of their habitat, it is not known whether or not the preferred habitat of either species exists in the Missouri River.

\section{Population-Forecasting Model}

Successful recovery of endangered fish species requires detailed understanding of their life history, the environments in which they live, and the aquatic community with which they interact. Fish have different ecological requirements throughout their ontogenetic development. The ability of fish to meet these requirements at various life stages determines the restrictive nature of potential ecological bottlenecks. Interactions with other individuals within the population and with other species within the community (for example, competition, predation) along with the use of the food resources (for example, macroinvertebrates) and the physical habitat in which they live determine the success of fishes for surviving each bottleneck. Individually-based models used in conjunction with explicit models of space incorporating spatial and temporal variation, could be used to predict the physiology, behavior, growth, survival, and reproduction of fishes under changing environmental conditions to estimate the restrictive nature of each bottleneck (Wildhaber and Lamberson, 2004). Such understanding requires integration of knowledge across multiple disciplines including biology, hydrology, geomorphology, and climatology.

One approach is to use mathematical and empirical models to integrate knowledge across disciplines to develop individual-based, spatially and temporally explicit models to benefit research, management, and monitoring efforts by predicting demographic trends under current and potential future conditions (Wildhaber and Lamberson, 2004). The environmental experience of individual fish of a given species varies greatly. This variation is a function of the individual, the environment in which it finds itself, and the choices it makes; this variation can translate into population trends that may not have been predicted based on the average individual. These spatial and temporal patterns of individuals can then be used within an age-structured demographic model that is compartmentalized by the stage-structured conceptual model presented in this report to forecast population changes (Bajer and Wildhaber, 2007). The latter model contains parameters for each age class that often includes the number of individuals, probability of survival to the next age class, and reproductive rate to name a few. Using this population matrix, estimates can be made as to whether or not a population is stable, increasing or declining, and which parameters of the population model (that is, age classes and associated parameters) have the most effect on the population.

An example of the value of such a modeling approach is demonstrated by Bajer and Wildhaber (2007) who developed age-structured demographic models for the pallid and shovelnose sturgeon in the Lower Missouri River to conduct sensitivity analyses for the populations. Potential effects of increased fishing mortality on the shovelnose sturgeon also were evaluated. Populations of pallid and shovelnose sturgeon were most sensitive to age zero mortality rates as well as mortality rates of juveniles and young adults. Overall, fecundity was a less sensitive parameter; however, increased fecundity effectively 
balanced greater mortality among sensitive age classes in both populations. The model predicts that management that increases population-level fecundity and improves survival of age zero, juveniles and young adults should most effectively benefit both populations. Evaluation of reproductive values indicated that populations of pallid sturgeon dominated by ages more than 35 years rapidly could lose their potential for growth, particularly if recruitment remains low. Under the initial parameter values the population of shovelnose sturgeon in the Lower Missouri River was predicted to decline by 1.65 percent annually, causing the commercial yield also to decline. Modeling indicated that the commercial yield could substantially increase if exploitation of females in ages less than 12 years was restricted.

\section{Summary}

In the model presented, human activities at the process level that affect survival, growth, and development are considered critical determinants of successful transition between all life stages, whereas non-human predation is not considered critical once the fish has reached the juvenile stage. For the human activities identified, entrainment is considered a critical determinant of successful transition between life stages once the fish has reached the larval stage, whereas fishing is considered critical only after the fish has reached the juvenile stage.

For rate-affecting processes identified as critical for survival, growth, and development, habitat is considered a critical determinant of successful transition between all life stages, whereas contaminants and disease are considered critical to all life stage transitions except from spawning adults with viable gametes to developing embryos. Prey availability and competition for food are considered critical once the fish reach the free embryo stage.

The critical rate-affecting processes help to determine which of the condition factors are critical to the life-stage transition being considered. Hydraulic habitat, sediment, temperature, water quality, and light are considered critical determinants of successful transition for all life stages. The presence of con-specifics is only considered critical once the adult life stage has been reached, whereas fish origin is considered a critical determinant of successful transition between all life stages once a developing embryo has been formed. Finally, the nature of the food web and the available nutrients are considered critical determinants of successful transition between all life stages once the exogenously feeding larval stage has been reached.

The conceptual model provided here was developed to organize the understanding of the complex life history of Scaphirhynchus sturgeons. It was designed for communication, planning, and to provide the structure for a populationforecasting model. These models are intended to be dynamic and responsive to new information and changes in river management, thereby providing scientists, stakeholders, and managers with ways to improve understanding of the effects of management actions on the ecological requirements of Scaphirhynchus sturgeons.

As new scientific knowledge becomes available, it could be included in these models in many ways at various levels of integration. The set of processes, conditions, and the connections between them that are identified in the conceptual life-history model were identified based on the current knowledge as supported by scientific publications. The components identified in the model and the connections between them could change when future data are collected that may improve the model. The cumulative knowledge of the scientific and management community dealing with sturgeon provide the assurance that the information on which the model is based in current and critical or missing data are identified. At the quantitative level, the transition probabilities, the strength of the connections between conditions and rate-affecting processes, rate-affecting processes and processes, and processes and transition probabilities (for example arrows), and submodels that empirically describe the processes are all defined by the data from basic research. Updating the scientific knowledge on which the model is based and using that base to define the current structure and parameterization of the model provides the ability to capture and track such changes in a working model that everyone can use.

\section{References Cited}

Arrington, D.A., and Winemiller, K.O. 2003, Diel changeover in sandbank fish assemblages in a neotropical floodplain river: Journal of Fish Biology, v. 63, p. 442-459.

Bailey, R.M., and Cross, F.B., 1954, River sturgeon of the American genus Scaphirhynchus: characters, distribution and synonymy: Papers of the Michigan Academy of Science, Arts and Letters, v. 39, p. 169-208.

Bajer, P.G., and Wildhaber, M.L., 2007, Population viability analysis of Lower Missouri River shovelnose sturgeon with initial application to the pallid sturgeon: Journal of Applied Ichthyology, v. 23, p. 457-464.

Balon, E.K., 1975, Reproductive guilds of fishes-A proposal and a definition: Journal of the Fisheries Research Board of Canada, v. 32, p. 821-864.

Becker, G.C., 1983, Fishes of Wisconsin: Madison, Wis., University of Wisconsin Press, 1,053 p.

Berry, C.R, Jr., Wildhaber, M.L. , and Galat, D.L. , 2005, Population structure and habitat use of benthic fishes along the Missouri and lower Yellowstone Rivers-Volume 3-Fish distribution and abundance: Final report of Missouri River benthic fish study PD-95-5832 to U.S. Army Corps of Engineers and Bureau of Reclamation, 268 p. 
Birstein, V.J., 1993, Sturgeons and paddlefishes-threatened fish in need of conservation: Conservation Biology, v. 7, p. 773-787.

Bramblett, R.G., and White, R.G., 2001, Habitat use and movements of pallid and shovelnose sturgeon in the Yellowstone and Missouri Rivers in Montana and North Dakota: Transactions of the American Fisheries Society, v. 130, p. 1,006-1,025.

Braaten, P.J., Fuller, D.B., and McClenning, N.D, 2007, Diet composition of larval and young-of-year shovelnose sturgeon in the upper Missouri River: Journal of Applied Ichthyology, v. 23, p. 517-521.

Braaten, P.J., and Fuller, D.B., 2005, Fort Peck flow modification biological data collection plan-summary of 2004 activities: Fort Peck, Mont., Montana Department of Fish, Wildlife and Parks, 63 p.

Breder, C.M., and Rosen, D.E., 1966, Modes of reproduction in fishes: Neptune City, N.J., T.F.H. Publications, 941 p.

Bruch, R.M., and Binkowski, F.P., 2002, Spawning behavior of lake sturgeon (Acipenser fulvescens): Journal of Applied Ichthyology, v. 18, p. 570-579.

Buckley, J., and Kynard, B., 1985, Habitat and behaviour of pre-spawning and spawning shortnose sturgeon, Acipenser brevirostrum, in the Connecticut River, in Binkowski, F.P., and Doroshov, S.I., eds., North American sturgeons-biology and aquaculture potential: Dordrecht, Netherlands, Junk Publishers, p. 111-117.

Campton, D.E., Bass, A.L., Chapman, F.A., and Bowen, B.W., 2000, Genetic distinction of pallid, shovelnose, and Alabama sturgeon-emerging species and the U.S. Endangered Species Act: Conservation Genetics, v. 1, p. 17-32.

Carlson, D.M., Pflieger, W.L., Trial, L., and Haverland, P.S., 1985, Distribution, biology, and hybridization of Scaphirhynchus albus and Scaphirhynchus platorynchus in the Missouri and Mississippi River: Environmental Biology of Fishes, v. 14, p. 51-59.

Cech and Doroshov, 2004, Environmental requirements, preferences, and tolerance limits of North American sturgeons, in LeBreton, G.T.O., Beamish, F.W.H., and McKinley, R.S., eds., Sturgeons and paddlefish of North America: Netherlands, Kluwer Academic Publishers, p. 73-86.

Christenson, L.M., 1975, The shovelnose sturgeon (Scaphirhynchus platorynchus Rafinesque) in the Red CedarChippewa Rivers system Wisconsin: Wisconsin Department of Natural Resources, Research Report Number 82, 23 p.

Deng, D.F., Koshio, S., Yokoyama, S., Bai, S.C., Shao, Q., Cui, Y., Hung, S.S.O, 2003, Effects of feeding rate on growth performance of white sturgeon (Acipenser transmontanus) larvae: Aquaculture, v. 217, p. 589-598.
Deng, X., Van Eenennaam, J.P., Doroshov, S.I., 2002, Comparison of early life stages and growth of green and white sturgeon: in Van Winkle, W., Anders, P.J., Secor, D.H., and Dixon, D.A. eds., Biology, management, and protection of North American sturgeon: Bethesda, Md., American Fisheries Society, Symposium 28, p. 237-248.

Dettlaff, T.A., Ginsburg, A.S, and Schmalhausen, O.I., 1993, Sturgeon fishes: Developmental biology and aquaculture: Berlin, Springer-Verlag, 300 p.

Dryer, M.P., and Sandvol, A.J., 1993, Recovery plan for the pallid sturgeon (Scaphirhynchus albus): Bismarck, N. Dak., U.S. Fish and Wildlife Service, 55 p.

Duffy, W.G., Berry, C.R., and Keenlyne, K.D., 1996, Biology of the pallid sturgeon with an annotated bibliography through 1994: Brookings, S. Dak., South Dakota State University, Cooperative Fish and Wildlife Research Unit, Technical Bulletin 5, 32 p.

Eddy, S., and Surber, T., 1947, Northern fishes with special reference to the Upper Mississippi Valley, (Revised Edition), Minneapolis, Minn., University of Minnesota Press, $276 \mathrm{p}$.

Ferrell, J., 1993, Big Dam Era-A legislative history of the Pick-Sloan Missouri River Basin Program: Omaha, Nebr., U.S. Army Corps of Engineers, 228 p.

Ferrell, J., 1996, Soundings-100 years of the Missouri River navigation project: U.S. Army Corps of Engineers, U.S. Government Printing Office: 1996-555-110, 171 p.

Forbes S.A., and Richardson, R.E., 1920, The fishes of Illinois; (2d ed.): Champagne, Ill., Natural History Survey of Illinois, v. 3, p. 1-357.

Fox, D.A., Hightower, J.E., and Parauka, F.M., 2000, Gulf sturgeon spawning migration and habitat in the Choctawhatchee River system, Alabama-Florida: Transactions of the American Fisheries Society, v. 129, p. 811-826.

Funk, J. L., and Robinson, J.W., 1974, Changes in the channel of the Lower Missouri River and effects on fish and wildlife: Jefferson City, Mo., Missouri Department of Conservation, $52 \mathrm{p}$.

Galat, D.L., and Lipkin, R., 2000, Restoring ecological integrity of great rivers: historical hydrographs aid in defining reference conditions for the Missouri River: Hydrobiologia, v. 422, p. 29-48.

Galat, D. L., Wildhaber, M.L., Dieterman, D.J. 2001, Population structure and habitat use of benthic fishes along the Missouri and Lower Yellowstone Rivers_-Volume 2-Spatial patterns of physical habitat variables along the Missouri and Lower Yellowstone Rivers: Final report of Missouri River benthic fish study PD-95-5832 to U.S. Army Corps of Engineers and Bureau of Reclamation, 91 p. 
Galat, D.L., Berry, C.R., Gardner, W.M., Hendrickson, J.C., Mestl, G.E., Power, G.J., Stone, C., and Winston, M.R., 2005, Spatiotemporal patterns and changes in Missouri River Fishes, in Rinne, J.N., Hughes, R.M., and Calamusso, B., eds., Historical changes in large river fish assemblages of the Americas: Bethesda, Md., American Fisheries Society Symposium, v. 45, p. 249-291.

George, S.G., Hoover, J.J., Murphy, C.E., and Killgore, K.J. 2007, The real poop on pallid sturgeon ecology - fecal analysis as a technique for reconstructing diet and inferring habitat and behavior: Journal of Applied Ichthyology, v. 23.

Gerrity, P.C., Guy, C.S., and Gardner, W.M., 2006, Juvenile pallid sturgeon are piscivorous - a call for conserving native cyprinids: Transactions of the American Fisheries Society, v. 135 , p. 604-609.

Gisbert, E., Dorosov, S.I., 2003, Histology of the developing digestive system and the effect of food deprivation in larval green sturgeon (Acipenser medirostris): Aquatic Living Resources, v. 16, p. 77-89.

Gisbert, E., Williot, P., 1997, Larval behavior and effect of the timing on initial feeding on growth and survival of Siberian sturgeon (Acipenser baeri) larvae under small scale hatchery production: Aquaculture, v. 156, p. 63-76.

Harshbarger, J.C., Coffey, M.J., and Young, M.Y., 2000, Intersexes in Mississippi River shovelnose sturgeon sampled below St. Louis, Mo., USA: Marine Environmental Research, v. 50 p. $247-250$.

Hesse, L.W., and Carreirov, J.R., 1997, The status of paddlefish, pallid sturgeon, lake sturgeon, and shovelnose sturgeon-a summary of information regarding status, distribution, and current management strategies within their present range: Bettendorf, Iowa, Mississippi Interstate Cooperative Resource Association, 52 p.

Hesse, L.W., and Sheets, W., 1993, The Missouri River hydrosystem: Fisheries, v. 18, p. 5-14.

Hesse, L.W., Schmulbach, J.C., Carr, J.M., Keenlyne, K.D., Unkenholz, D.G., Robinson, J.W., and Mestl, G.E., 1989, Missouri River fishery resources in relation to past, present, and future stresses, in Dodge, D.P., ed., Proceedings of the International Large River Symposium: Canadian Special Publication of Fisheries and Aquatic Sciences, v. 106, p. 352-371.

Houston, J.J., 1988, Status of the green sturgeon, Acipenser medirostris, in Canada: The Canadian Field Naturalist, v. 102 , p. 286-290.

Hrabik, R.A., Herzog, D.P., Ostendorf, D.E., and Petersen, M.D., 2007, Larvae provide first evidence of successful reproduction by pallid sturgeon, Scaphirhyncus albus, in the
Mississippi River: Journal of Applied Ichthyology, v. 23, p. $436-443$.

Humphries, P., Serafini, L.G., and King, A.J., 2002, River regulation and fish larvae: variation through space and time: Freshwater Biology, v. 47, p. 1,307-1,331.

Hurst, T.P., Conover, D.O., 1998, Winter mortality of youngof-the-year Hudson River striped bass (Morone saxatilis)_-size-dependent patterns and effects on recruitmen: Canadian Journal of Fisheries and Aquatic Sciences, v. 55, p. 1,122-1,130.

Jobling, M., 1995, Environmental biology of fishes: London, Chapman and Hall, 455 p.

Jordan, G.R., 2006, Pallid sturgeon (Scaphirhynchus albus) range-wide stocking and augmentation plan: Billings, Mont., U.S. Fish and Wildlife Service, 79 p.

June, F.C., 1977, Reproductive patterns in seventeen species of warmwater species in a Missouri River reservoir: Environmental Biology of Fishes, v. 2, p. 285-296.

Kapuscinski, K., 2002, Population abundance estimation of wild pallid sturgeon in recovery-priority management area \#2 of the Missouri and Yellowstone Rivers during 1991-2001 in 2002 upper basin pallid sturgeon work group annual report: Fort Peck, Mont., Montana Department of Fish, Wildlife and Parks, p. 294.

Keenlyne, K.D., 1997, Life history and status of the shovelnose sturgeon, Scaphirhynchus platorynchus: Environmental Biology of Fishes, v. 48, p. 291-298.

Keenlyne K.D., Jenkins L.G., 1993, Age at sexual maturity of the pallid sturgeon: Transactions of the American Fisheries Society, v. 122, p. 393-396.

Keenlyne, K.D., Graham, L.K., and Reed, B.C., 1994, Hybridization between the pallid and shovelnose sturgeons: Proceedings of the South Dakota Academy of Science, v. 73, p. 59-66.

Kynard, B., Henyey, E., Horgan, M., 2002, Ontogenetic behavior, migration, and social behavior of pallid sturgeon, Scaphirhynchus albus, and shovelnose sturgeon, S. platorynchus, with notes on the adaptive behavior of body color: Environmental Biology of Fishes, v. 63, p. 389-403.

LaHaye, M., Branchard, A., Gendron, M., Verndon, R., and Fortin, R., 1992, Reproduction, early life history, and characteristics of the spawning grounds of the lake sturgeon (Acipenser fulvescens) in Des Prairies and L'Assomption Rivers near Montreal, Quebec: Canadian Journal of Zoology, v. 70, p. 1,681-1,689.

Leslie, J.K., and Timmins, C.A., 1998a, Age 0+ fish occurrence in modified habitat in south-western Ontario: Cana- 
dian Technical Report of Fisheries and Aquatic Sciences, p. 2,219.

Leslie, J.K., and Timmins, C.A., 1998b, Seasonality of fish larvae in surf zone and tributary of Lake Erie-a comparison: Canadian Technical Report of Fisheries and Aquatic Sciences, p. 2,197.

Mayden R.L., Kuhajda B.R., 1996, Systematics, taxonomy, and conservation status of the endangered Alabama sturgeon, Scaphirhynchus suttkusi Williams and Clemmer (Actinopterygii, Acipenseridae): Copeia, v. 2, p. 241-273.

Mayden R.L, Kuhajda B.R., 1997, Threatened fishes of the world: Scaphirhynchus albus (Forbes \& Richardson, 1905) (Acipenseridae): Environmental Biology of Fishes, v. 48, p. $420-421$.

Modde, T., and Schmulbach, J.C., 1977, Food and feeding behavior of the shovelnose sturgeon, Scaphirhynchus platorynchus, in the unchannelized Missouri River, South Dakota: Transactions of the American Fisheries Society, v. 106, p. 602-608.

Moos, R.E., 1978, Movement and reproduction of shovelnose sturgeon Scaphirhynchus platorynchus (Rafinesque) in the Missouri River, South Dakota: Vermillion, South Dakota, University of South Dakota, Ph.D. Dissertation, 213 p.

Munro, A.D., Li-Lianb, C., and Nqankee, K., 1990, Preliminary observation on environmental control of ovulation and spawning in a small tropical Cyprinid (Barbus tetrazona), Proceedings: Tokyo, Japan, Second Asian Fisheries Forum, p. 17-22.

NatureServe, 2005, NatureServe Explorer: An online encyclopedia of life [web application] (Version 4.5): Arlington, Virginia, NatureServe, [accessed October 19, 2005, at http:/7 www.natureserve.org/explorer.

Parsley, M.J., Anders, P.J., Miller, A.I., Beckman, L.G., and McCabe, G.T., Jr., 2002, Recovery of white sturgeon populations through natural production-understanding the influence of abiotic and biotic factors on spawning and subsequent recruitment, in Van Winkle, W., Anders, P.J., Secor, D.H., and Dixon, D.A., eds., Biology, management, and protection of North American sturgeon: Bethesda, Md., American Fisheries Society, Symposium 28, p. 55-66.

Pflieger, W.L., 1997, The fishes of Missouri: Jefferson City, Mo., Missouri Department of Conservation, 372 p.

Pflieger, W.L., and Grace, T.B., 1987, Changes in the fish fauna of the Lower Missouri River, in Matthews, W.J., and Heins, D.C., eds, Community and evolutionary ecology of North American stream fishes: Norman, Okla., University of Oklahoma Press, p. 1,940-1,983.

Quist, M.C., Guy, C.S., Pegg, M.A., Braaten, P.J., Pierce, C.L., Travnichek, V.H., 2002, Potential influence of harvest on shovelnose sturgeon populations in the Missouri River system: North American Journal of Fisheries Management, v. 22 , p. $537-549$.

Quist, M.C., Boelter, A.M., Lovato, J.M., Korfanta, N.M., Bergman, H.L., Latka, D.C., Korschgen, C., Galat, D.L., Krentz, S., Oetker, M., Olson, M., Scott, C.M., and Berkley, J., 2004, Research and assessment needs for pallid sturgeon recovery in the Missouri River-Final report to the U.S. Geological Survey, U.S. Army Corps of Engineers, U.S. Fish and Wildlife Service, and U.S. Environmental Protection Agency: Laramie, Wyo., William D. Ruckelshaus Institute of Environment and Natural Resources, University of Wyoming, $82 \mathrm{p}$.

Rankin, J.C., Pitcher, T.J., and Duggan, R.T., 1983, Control processes in fish physiology: New York, John Wiley and Sons, p. 298.

Rosenblum, P.M., Pudney, J., Callard, I.P., 1987, Gonadal morphology, enzyme histochemistry and plasma steroid levels during the annual reproductive cycle of male and female brown bullhead catfish, Ictalurus nebulosus Lesueur: Journal of Fish Biology, v. 31 p. 325-261.

Ruelle, R., and Keenlyne, K.D., 1993, Contaminants in Missouri River pallid sturgeon: Bulletin of Environmental Contamination and Toxicology, v. 50, p. 898-906.

Scheidegger, K.J., and Bain, M.B., 1995, Larval fish in natural and regulated rivers: assemblage composition and microhabitat use: Copeia, v. 1, p. 125-135.

Schiemer, F., Keckeis, H., Winkler, G., and Flore, L., 2001, Large rivers- the relevance of ecotonal structure and hydrological properties for the fish fauna: Archives für Hydrobiologie Supplement 135-Large Rivers, v. 12, p. 487-508.

Scott, W.B., and Crossman, E.J., 1973, Freshwater fishes of Canada: Fisheries Research Board of Canada Bulletin, v. $184,966 \mathrm{p}$.

Scott, M.T., and Nielsen, L.A., 1989, Young fish distribution in backwaters and main-channel borders of the Kanawha River, West Virginia: Journal of Fish Biology, v. 35, p. 21-27.

Simons, A.M., Wood, R.M., Heath, L.S., Kuhajda, B.R., and Mayden, R.L., 2001, Phylogenetics of Scaphirhynchus based on mitochondrial DNA sequences: Transactions of the American Fisheries Society, v. 130, p. 359-366.

Snyder, D.E., 2002, Pallid and shovelnose sturgeon larvaemorphological description and identification: Journal of Applied Ichthyology, v. 18, p. 240-265.

Sullivan, C.V., Berlinksky, D.L., Hodson, R.G., 1997, Reproduction, in Harrell, R.M., ed., Striped bass and other morone culture: Amsterdam, Netherlands, Elsevier Sciences, p. 11-73. 
Surprenaut, C., 2004, Scaphirhynchus platorynchus, in IUCN 2004, 2004 IUCN Red list of threatened species: [downloaded on October 17, 2005, at http://www.iucnredlist.org].

Taubert, B.D., 1980, Reproduction of shortnose sturgeon (Acipenser brevirostrum) in Holyoke Pool, Connecticut River, Mass.: Copeia, v. 1,980, p. 114-117.

Tockner, K., and Stanford, J.A., 2000, Riverine floodplains: present state and future trends: Environmental Conservation, v. 29, p. 308-330.

U.S. Fish and Wildlife Service, 2000, Biological opinion on the operation of the Missouri River main stem reservoir system, operation and maintenance of the Missouri River bank stabilization and navigation project, and operation of the Kansas River reservoir system: Bismarck, N. Dak., U.S. Fish and Wildlife Service, 286 p.

U.S. Fish and Wildlife Service, 2003, Amendment to the 2000 biological opinion on the operation of the Missouri River main stem reservoir system, operation and maintenance of the Missouri River bank stabilization and navigation project, and operation of the Kansas River reservoir system: Minneapolis, Minn., U.S. Fish and Wildlife Service, 308 p.

Van Eenennaam, J.P., Linares-Casenave, J., Deng, X., and Doroshov, S.I., 2005, Effect of incubation temperature on green sturgeon embryos, Acipenser medirostris: Environmental Biology of Fishes, v. 72, p. 145-154.

Van Eenennaam, J.P., Doroshov, S.T., Moberg, G.P., Watson, J.G., Moore, D.S., and Linares, J., 1996, Reproductive conditions of the Atlantic sturgeon (Acipenser oxyrinchus) in the Hudson River: Estuaries, v. 19, p. 769-777.

Vanni, M. J., 1996. Nutrient transport and recycling by consumers in lake food webs: implications for algal communities, in Polis, G.A. and Winemiller, K.0., eds., Food
webs-Integration of patterns and dynamics: Chapman and Hall, p. 81-95.

Wildhaber, M.L., and Lamberson, P.J., 2004, Importance of the habitat choice behavior assumed when modeling the effects of food and temperature on fish populations: Ecological Modelling, v. 175, p. 395-409.

Wildhaber, M.L., Papoulias, D.M., DeLonay, A.J., Tillit, D.E., Bryan, J.L., Annis, M.L., and Allert, J.A., 2005, Gender identification of shovelnose sturgeon using ultrasonic and endoscopic imagery and the application of the method to the pallid sturgeon: Journal of Fish Biology, v. 67, p. 114-132.

Wildhaber, M.L., Papoulias, D.M., DeLonay, A.J., Tillitt, D.E., Bryan, J.L., and Annis, M.L., 2006, Development of methods to determine the reproductive status of pallid sturgeon in the Missouri River: U.S. Geological Survey, 81 p.

Williams, J.E., Johnson, J.E., Hendrickson, D.A., Contreras-Balderas, S., Williams, J.D., Navarro-Mendoza, M., McAllister, D.E., and Deacon, J.E., 1989, Fishes of North America endangered, threatened, or of special concern1989: Fisheries, v. 14, no. 6, p. 2-20.

Williamson, D.F., 2003, Caviar and conservation-Status, management, and trade of North American sturgeon and paddlefish: Washington, D.C., TRAFFIC North America, World Wildlife Fund, p. 252.

Wills, P.S., Sheehan, R.J., Heidinger, R., Sloss, B.L., and Clevenstine, R., 2002, Differentiation of pallid sturgeon and shovelnose sturgeon using and index based on meristics and morphometrics, in Van Winkle, W., Anders, P.J., Secor, D.H., and Dixon, D.A., eds., Bethesda, Md., Biology, management, and protection of North American sturgeon: American Fisheries Society, Symposium 28, p. 
Publishing support provided by: Rolla Publishing Service Center

For more information concerning this publication, contact: Director, USGS Columbia Environmental Research Center 4200 New Haven Road

Columbia, MO 65201

(573) 875-5399

Or visit the Columbia Environmental Research Center Web site at: http://www.cerc.usgs.gov 




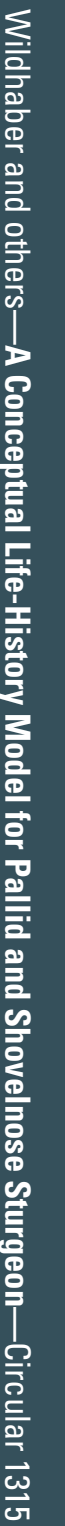

